\title{
Pliocene and Pleistocene volcanic interaction with Cordilleran ice sheets, damming of the Yukon River and vertebrate Palaeontology, Fort Selkirk Volcanic Group, west-central Yukon, Canada
}

\author{
L.E. Jackson Jr. ${ }^{\mathrm{a}, *}$, F.E. Nelson ${ }^{\mathrm{b}, 1}$, C.A. Huscroft ${ }^{\mathrm{c}}$, M. Villeneuve ${ }^{\mathrm{d}}$, R.W. Barendregt ${ }^{\mathrm{b}}$, J.E. Storer ${ }^{\mathrm{e}}$, B.C. Ward $^{\mathrm{f}}$ \\ ${ }^{a}$ Geological Survey of Canada, Natural Resources Canada, 625 Robson Street, Vancouver, BC V6B5J3, Canada \\ ${ }^{\mathrm{b}}$ Department of Geography, University of Lethbridge, 4401 University Drive, Lethbridge, Alberta T1K 3M4, Canada \\ ${ }^{c}$ Department of Geography, Thompson Rivers University, Box 3010, 900 McGill Road, Kamloops, BC V2C 5N3, Canada \\ ${ }^{\mathrm{d}}$ Geological Survey of Canada, 601 Booth Street, Ottawa, Ontario, Canada \\ e 6937 Porpoise Drive, Sechelt, BC V0N 3A4, Canada \\ ${ }^{\mathrm{f}}$ Department of Earth Sciences, Simon Fraser University, 8888 University Drive, Burnaby, BC V2C 5N3, Canada
}

\section{A R T I C L E I N F O}

Article history:

Available online $\mathrm{xxx}$

\begin{abstract}
A B S T R A C T
Neogene volcanism in the Fort Selkirk area began with eruptions in the Wolverine Creek basin ca. $4.3 \mathrm{Ma}$ and persisted to ca. 3.0 Ma filling the ancestral Yukon River valley with at least $40 \mathrm{~m}$ of lava flows. Activity at the Ne Ch'e Ddhäwa eruptive center overlapped with the last stages of the Wolverine Creek eruptive centers. Hyaloclastic tuff was erupted between ca. 3.21 and $3.05 \mathrm{Ma}$. This eruption caused or was coincident with damming of Yukon River. The first demonstrable incursion of a Cordilleran ice sheet into the Fort Selkirk area was coincident with a second eruption of the Ne Ch'e Ddhäwa eruptive center ca. 2.1 Ma. The Ne Ch'e Ddhäwa subglacial mound was erupted beneath at least $300 \mathrm{~m}$ of glacial ice (Ne Ch'e Ddhäwa Glaciation). The Eruption of the Fort Selkirk center occurred between the last eruption of Ne Ch'e Ddhäwa and Fort Selkirk Glaciation (ca. 2.1-1.5 Ma). Till and outwash from Fort Selkirk Glaciation are conformably overlain by nonglacial sediments that contain the Fort Selkirk tephra (fission track dated at ca. $1.5 \mathrm{Ma}$ ). These nonglacial sediments also preserve a short magnetic reversal (reversed to normal) identified as the Gilsá polarity excursion. Temporal control and sedimentology constrain Fort Selkirk Glaciation and the Fort Selkirk Local Fauna to marine isotope stage 54. Rapid and extensive eruption of the Pelly eruptive center filled the Yukon River valley with $70 \mathrm{~m}$ of lava which buried these glacial and nonglacial sediments and dammed Yukon River. Local striations and erratic pebbles occur on the last of these lava flows. They document a subsequent incursion of glacial ice during the last $500 \mathrm{ka}$ of the Matuyama Chron (Forks Glaciation). The last major eruption of mafic lava occurred in the middle Pleistocene west of (early Holocene) Volcano Mountain in basin of Black Creek: lava flowed down the valley presently occupied by Black Creek and dammed Yukon River in the area of the Black Creek confluence. This eruption predated the middle Pleistocene Reid Glaciation. Minor volcanism has continued in this area since the middle Pleistocene at Volcano Mountain.
\end{abstract}

(c) 2011 Elsevier Ltd and INQUA. All rights reserved.

\section{Introduction}

The eruptive history of mafic volcanic centers in the Fort Selkirk area, Yukon Territory (Figs. 1 and 2), extends from the mid Pliocene to the latest Pleistocene or early Holocene (Jackson et al., 2008; Nelson et al., 2009). Lava flows, hyaloclastites and interstratified

\footnotetext{
* Corresponding author. Fax: +1 6046661124

E-mail address: lijackso@nrcan.gc.ca (L.E. Jackson).

1 Present address: Department of Geology, University of Otago, Dunedin 9054 New Zealand.
}

sediments are collectively referred to as the Fort Selkirk Volcanic Group (FSVG; Bostock, 1936). FSVG is situated within the western limits of late Pliocene and early Pleistocene Cordilleran ice sheets. Radiometric dating and investigation of the paleomagnetism of volcanic rocks and interstratified glacial and nonglacial sediments have constrained the ages of the most extensive late Pliocene and early Pleistocene ice sheets that pressed into this region, and have allowed glacial deposits to be correlated to the marine oxygen isotopic record.

This paper adds additional and revised numerical ages for eruption of FSVG and associated volcanic damming of the paleoYukon River. It expands and refines the chronology of regional 


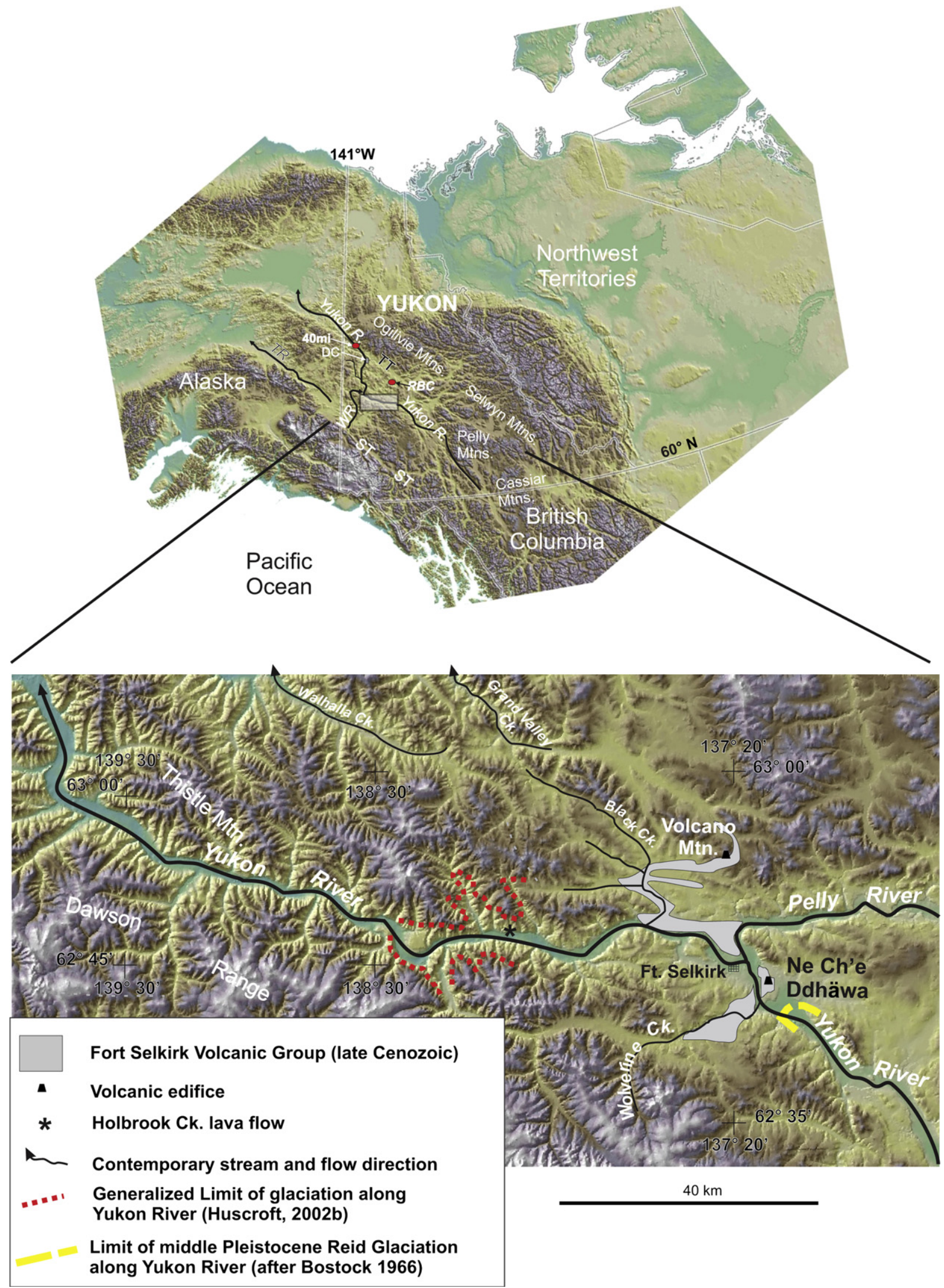

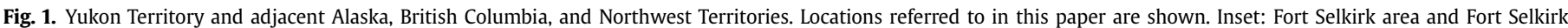

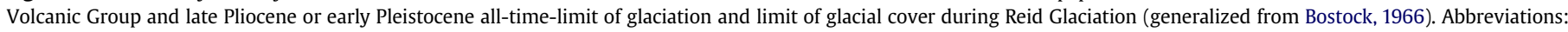

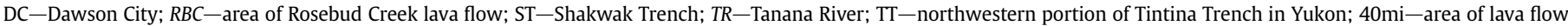
near the village of Fortymile; WR-White River.

Please cite this article in press as: Jackson, L.E., Jr.et al., Pliocene and Pleistocene volcanic interaction with Cordilleran ice sheets, damming of the Yukon River and vertebrate Palaeontology, Fort Selkirk Volcanic Group, west-central Yukon, Canada, Quaternary International (2011), doi:10.1016/j.quaint.2011.08.033 


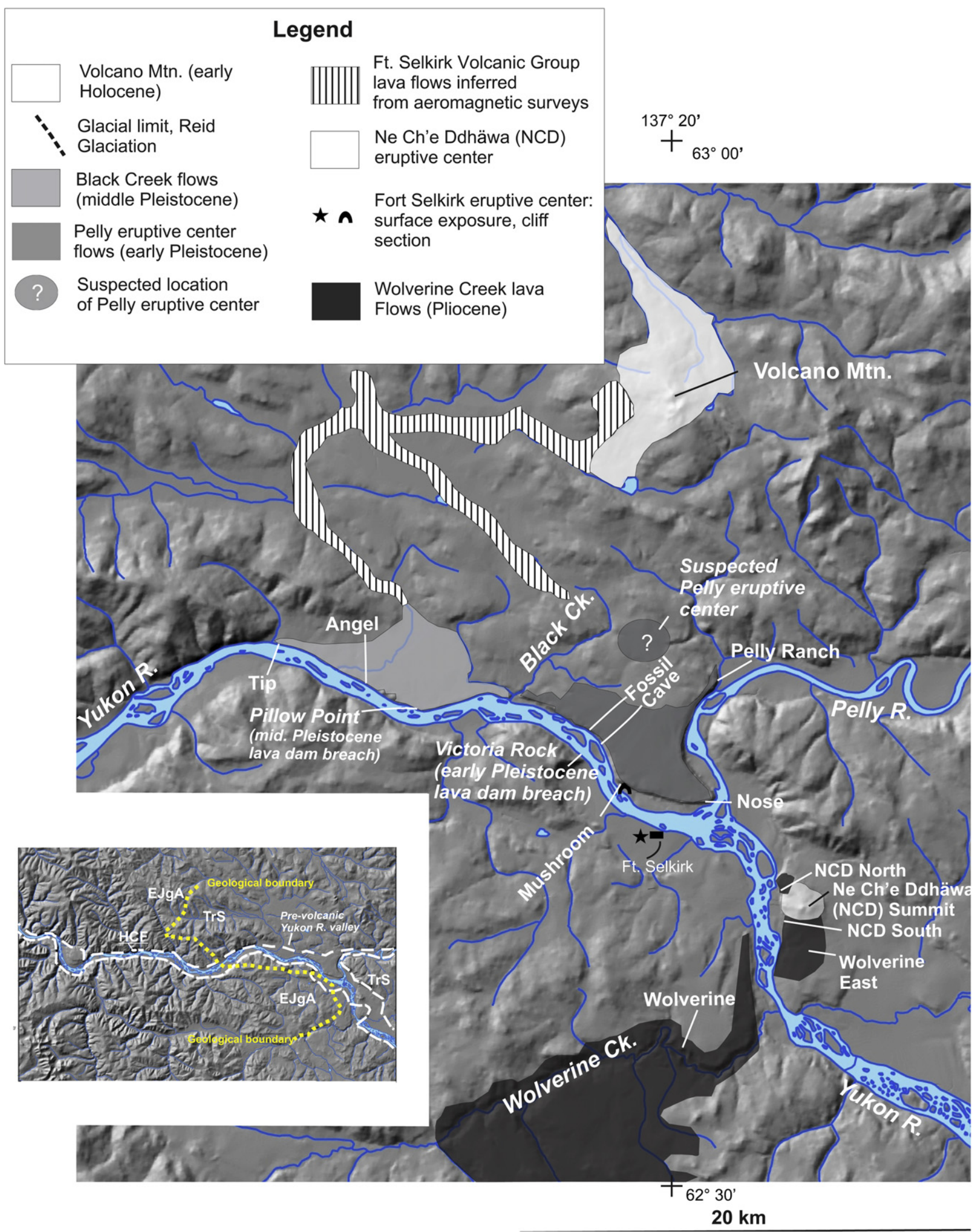

Fig. 2. Eruptive centers of Fort Selkirk Volcanic Group and location of sections and other sites referred to in text and other figures. Inset: pre-volcanic valley of Yukon River and its bedrock geology (Ryan et al., 2010); HCF-isolated lava flow at the mouth of Holbrook Creek. 
glaciation in Yukon during the obliquity-driven glaciations of the late Pliocene and early Pleistocene (Raymo and Huybers, 2008). The age of an early Pleistocene vertebrate fossil assemblage, the Fort Selkirk Local Fauna (FSLF) (Storer, 2003, 2004) is further constrained. Based upon the age of FSLF, paleontologic evidence is presented to suggest that the Cape Deceit Fauna, which is among the oldest recording cold adapted Arctic Ocean borderland biota in North America, dates to the Olduvai subchron or an older normal magnetic interval.

\section{Background}

\subsection{Physiographic and geologic setting}

The Fort Selkirk area (Figs. 1 and 2) lies within the Yukon Plateaus (Mathews, 1986), a rolling incised upland with elevations ranging from $430 \mathrm{~m}$ along Yukon River up to $1940 \mathrm{~m}$. Total relief seldom exceeds $600 \mathrm{~m}$. The basement rocks in the eastern part of the Fort Selkirk area are predominantly underlain by dacite to andesite flows and volcanoclastic rocks of the Triassic Seminoff Formation (uTrS) that are altered to greenstone in some areas (Fig. 2). The western portion of the area is underlain by Jurassic granodiorite and monzogranite of the Aishihk Suite (Ryan et al., 2010). Both eastern and western basement rocks are discontinuously overlain by remnants of late Cretaceous predominantly andesitic flood lavas of the Carmacks Group (Grond et al., 1984). The late Cenozoic Fort Selkirk Volcanic Group (FSVG) includes small volcanic edifices, extensive mafic lava flows and hyaloclastite. Flows and hyaloclastite fill valleys that are clearly graded to the valley occupied by contemporary Yukon River. These lava flows reach cumulative thicknesses of up to $145 \mathrm{~m}$ and form impressive palisades in the area of the confluence of the Yukon and Pelly rivers. FSVG locally contains interstratified sediments (Owen, 1959a,b) that include an early Pleistocene vertebrate fauna (Storer, 2003, 2004).

The fill of lava flows and hyaloclastite sediments delineate the course and elevation of a paleo-Yukon River and its tributaries prior to the eruption of FSVG (Fig. 2). The pre-volcanic width of the Yukon River valley changes with bedrock lithology and is apparently the product of differential lateral fluvial erosion: within the recessive volcanic rocks of the Seminoff Formation, the pre-FSVG Yukon River valley was $3-5 \mathrm{~km}$ wide but to the west (downstream) within the crystalline rocks of the Aishihk Suite its width narrowed to $1-2 \mathrm{~km}$.

Accurate mapping of FSVG away from the Yukon River valley is hampered by the overlying covering of glacial sediments, loess and extensive bog and fen deposits that contain discontinuous permafrost and support a dense boreal forest cover. Recent high resolution aeromagnetic mapping (e.g. Kiss and Coyle, 2009) has been useful in identifying FSVG where it fills late Cenozoic valley systems graded to Yukon River. However, the older Carmacks Group and Seminoff Formation have similar magnetic properties. Consequently, determination of exact location of eruptive vents of FSVG is difficult in upland settings.

Fort Selkirk is about $70 \mathrm{~km}$ downstream from the limit of the last Cordilleran ice sheet (McConnell Glaciation: marine isotope stage (MIS) 2) and $10 \mathrm{~km}$ downstream from the limit of the Cordilleran ice sheet that formed during the penultimate MIS 6 Reid Glaciation (Ward et al., 2008) (Fig. 2). Erratics and glacial meltwater features in the surrounding uplands indicate that all but the highest ridges in the Fort Selkirk area were glaciated prior to the Reid Glaciation (Bostock, 1966; Jackson, 2000). Drift that lies beyond the Reid glacial limit is eroded and discontinuous. It represents at least seven glaciations based on the glacial record reported from the Tintina Trench to the northwest (Fig. 1). These glaciations range in estimated age from as early as 2.6-2.9 Ma to 0.78 Ma (Froese et al., 2000; Duk-Rodkin et al., 2001, 2004, 2010). Drift beyond the limit of ice cover during the Reid Glaciation has been collectively referred to as 'pre-Reid'. The all-time (pre-Reid) limit of glaciation in the Yukon River valley is about $55 \mathrm{~km}$ to the west of Fort Selkirk (Huscroft, 2002a,b). Extensive erosion of preReid glacial deposits and burial beneath cryoturbated middle and late Pleistocene eolian and organic sediments generally precludes subdivision of individual pre-Reid drift sheets in the Fort Selkirk area.

Discrimination of individual pre-Reid glaciations in west-central Yukon has come largely as a result of the application of tephro- and magnetostratigraphy. Tephras from the Wrangell and Aleutian volcanic provinces have frequently fallen over west-central Yukon during at least the last $3 \mathrm{Ma}$ (e.g. Westgate et al., 2001, 2009). These provide maximum or minimum ages to overlying or underlying drift or paleosols where tephras can be dated numerically. Unfortunately, most tephras in west-central Yukon are not suitable for direct radiometric dating. However, they have proven to be chemically or mineralogically distinct: they can establish relative age of underlying glacial or nonglacial sediments. Paleomagnetic investigations of tephras, paleosols, glacial and nonglacial fluvial and lacustrine sediment, as well as till, have established a magnetostratigraphic record that can be related to the geomagnetic polarity timescale (Cande and Kent, 1995).

Tephrochronology, magnetostratigraphy and paleosol characteristics have been combined to broadly limit ages e.g. Froese et al. (2000) whereas volcanic rocks can be dated radiometrically and are also excellent recorders of earth's magnetic field at the time of their eruption. Where volcanic rocks are interstratified with glacial and interglacial sediments or where they were erupted beneath or in contact with glacial ice, they constrain the age and extent of glaciations and interglaciations. The Fort Selkirk area offers many such opportunities.

\subsection{Previous work and rationale for revisiting the glacial and volcanic chronology of the Fort Selkirk area}

Jackson et al. (1996) and Jackson (2000) established a chronology for eruptions and glaciations recorded at Fort Selkirk using $\mathrm{K}-\mathrm{Ar}$ dating and paleomagnetism. Based upon their interpretation of polarity data and reliable $\mathrm{K}-\mathrm{Ar}$ ages of the basalts, they concluded that the eruptions most-likely were restricted to the middle and late Matuyama Chron (1.77-0.99 Ma; Cande and Kent, 1995). They attributed what they perceived to be erroneously old radiometric ages to suspected retention of mantle argon within the dated rocks.

Subsequent investigations have shown that the FSVG was erupted over a longer span of time and its stratigraphy was more complicated than previously assumed by Jackson et al. (1996). Westgate et al. (2001) attributed a magnetic polarity reversal within sediments interstratified within FSVG to a brief reversal in the middle part of Matuyama Chron. This magnetic polarity reversal had been attributed to the Jaramillo or Cobb Mountain subchrons (within the latter part of the Matuyama Chron) by Jackson et al. (1996). Froese et al. (2001) referred this event to the brief Gilsá excursion (ca. 1.5 Ma; Clement and Kent, 1987) based upon isothermal plateau fission-track dating of overlying tephra and $\mathrm{Ar}-\mathrm{Ar}$ dating of overlying basalt flows, respectively: the basalt flows underlying the Fort Selkirk tephra and outwash sediments of the Fort Selkirk Glaciation (Fig. 3, Mushroom section) have been constrained by $\mathrm{Ar}-\mathrm{Ar}$ and $\mathrm{K}-\mathrm{Ar}$ ages to the 2.23-1.83 Ma range (Nelson et al., 2009). The application of $\mathrm{Ar}-\mathrm{Ar}$ dating was particularly important because it dismissed concerns about inherited mantle argon and indicated that the westerly bias in 


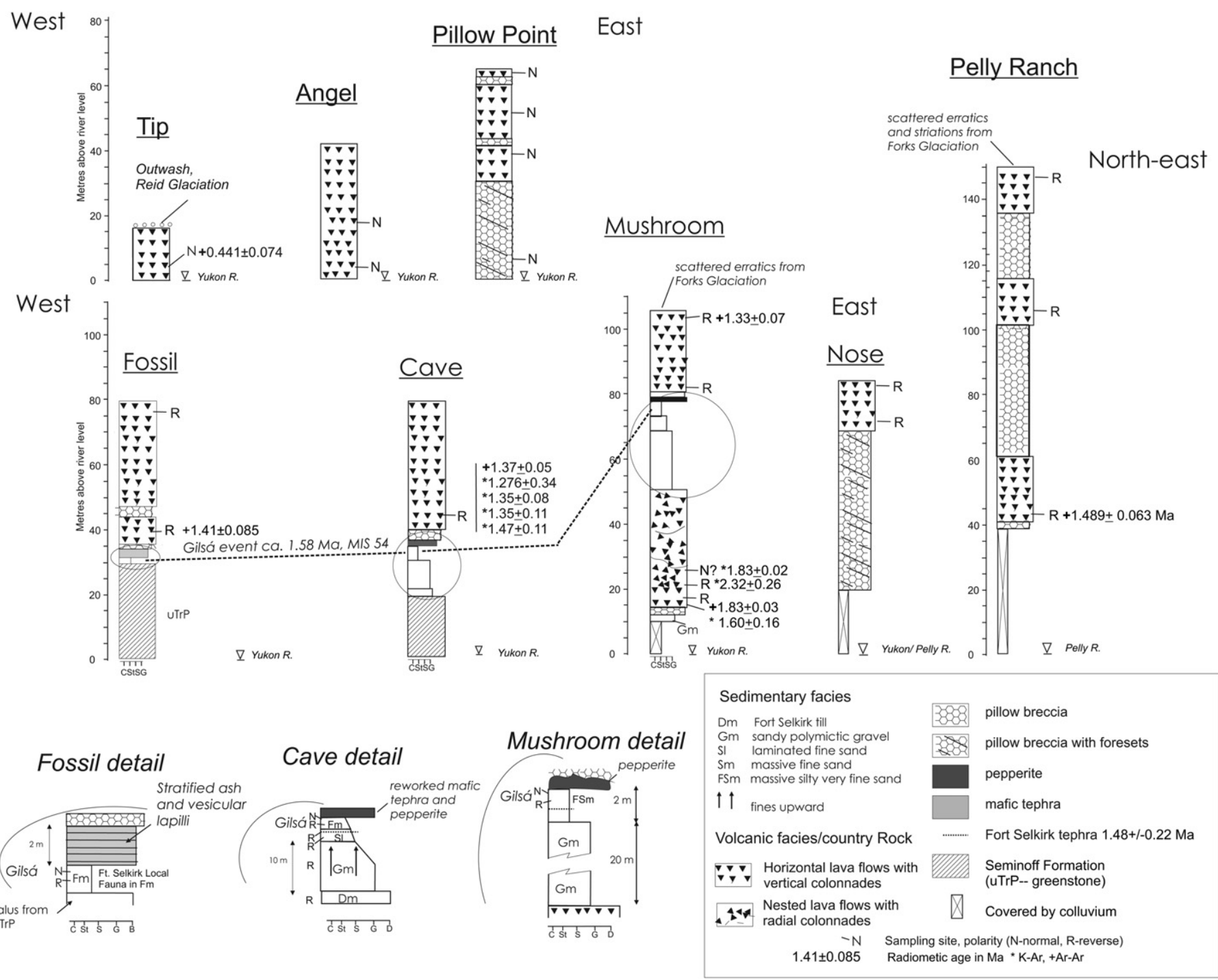

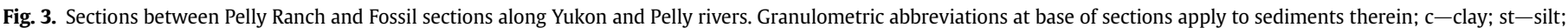
s-sand; g-gravel; b-boulder; d-diamicton.

paleomagnetism noted by Jackson et al. (1996) was not an artefact of eruption of FSVG over a short period of time.

Huscroft (2002a) and Huscroft et al. (2004) reported normal polarity FSVG lavas from lava flows along Yukon River in the Black Creek area (Figs. 2 and 3). They were radiometrically dated to the middle Pleistocene. They also demonstrated that these flows temporarily dammed the Yukon River.

This paper reports new or revised $\mathrm{Ar}-\mathrm{Ar}$ radiometric ages, supplementary field work carried out over the past decade and integrate them with magnetostratigraphy reported by Nelson et al. (2009) to provide a more comprehensive picture of the late Pliocene to middle Pleistocene eruptive history of FSVG, its interaction with successive early Quaternary ice sheets and Yukon River.

\subsubsection{Radiometric dating methodology}

New radiometric ages reported in this paper and those incorporated in Nelson et al. (2009) were produced using laser ${ }^{40} \mathrm{Ar} /{ }^{39} \mathrm{Ar}$ step heating analysis carried out at the laboratories of the Geological Survey of Canada, in Ottawa, Ontario following the procedures detailed in Nelson et al. (2009). Details of data collection and analytical protocols are outlined in Villeneuve and MacIntyre (1997) and Villeneuve et al. (2000). Error analysis on individual heating steps follows numerical error analysis routines outlined in Scaillet (2000). All error values associated with $\mathrm{Ar}-\mathrm{Ar}$ age determinations reported here for the first time and those in Nelson et al. (2009) are 2 sigma.

\section{Eruptive history of Fort Selkirk Volcanic Group}

FSVG (Fig. 2) consists of assemblages of mafic lava flows, pillow breccia, hyaloclastite tuff and volcanic edifices (Jackson, 1989; Francis and Ludden, 1990; Jackson et al., 1996) related to five eruptive centers. They include interstratified glacial and nonglacial sediments (Figs. 3 and 4). These are addressed in order of age (Table 1). Eruptive facies of these assemblages were described in detail in Jackson et al. (1996), Huscroft et al. (2004) and Nelson (2006). The reader is directed to those sources for comprehensive details of eruptive facies. Specifics concerning eruptive environments and facies are addressed in this paper as they directly relate to the glacial record and evolution of Yukon River. Examples are presented in Fig. 5. Fig. 6 summarizes the paleomagnetism of volcanic rocks by their respective eruptive center and interstratified sediments by site. Fig. 7 plots radiometric ages of lavas and their polarities (Cande and Kent, 1995) and the record of $\delta^{18} \mathrm{O}$ variation in 


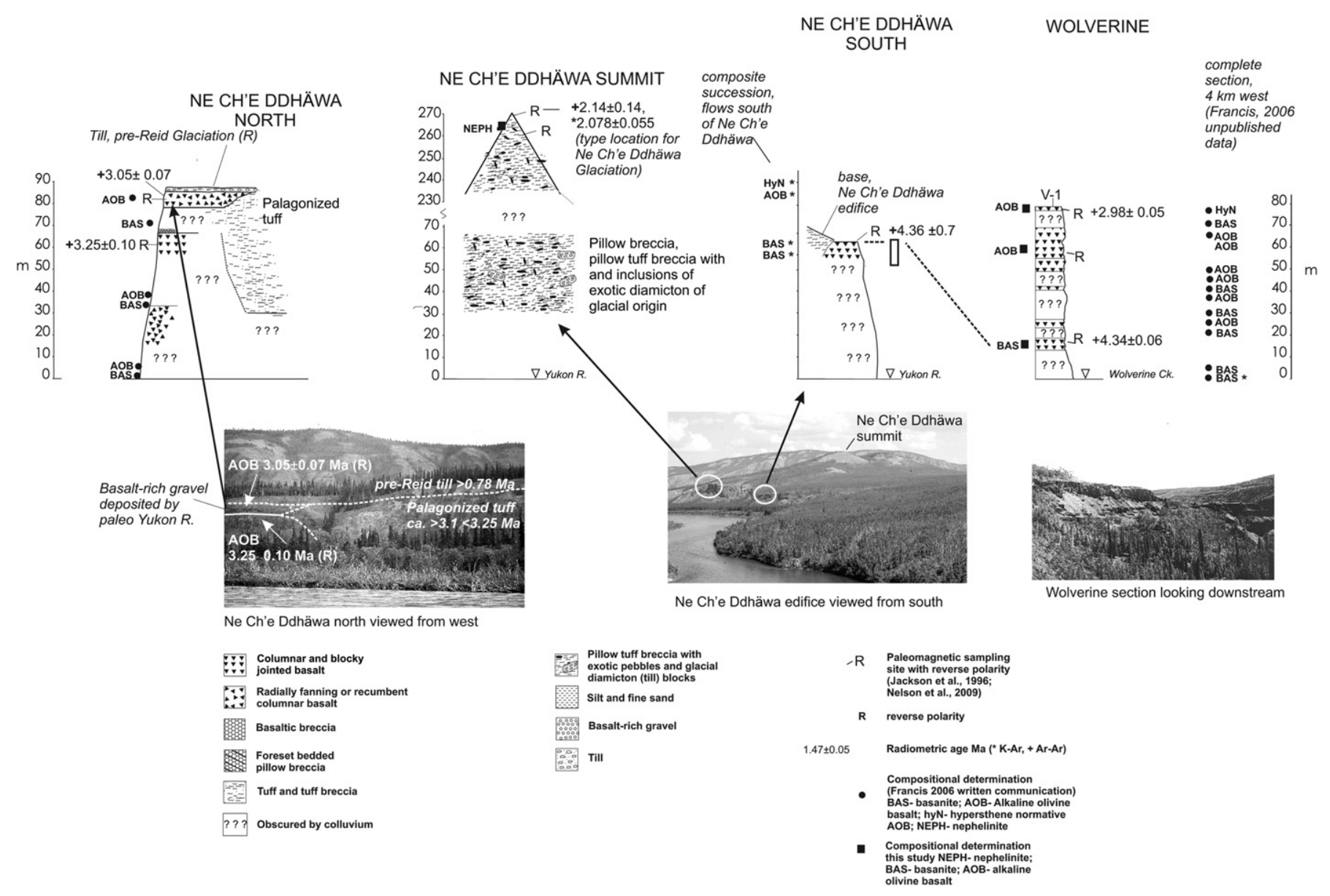

Fig. 4. Sections between Wolverine Creek and Ne Ch'e Ddhäwa (NCD) eruptive centers.

benthic fauna from the Lisieki-Raymo composite stack of marine cores (Lisiecki and Raymo, 2005). Chemical analysis of eruptive sequences was carried out by Francis and Ludden (1990). These analyses were used, and field research did not routinely determine the chemistry of volcanic rocks which were sampled. Consequently, field terms such as 'olivine basalt' or 'mafic lapilli' are used in descriptions of volcanic successions rather than normative classifications.

\subsection{Wolverine sequence}

Lava flows of the Wolverine sequence (Francis and Ludden, 1990) are the oldest of the FSVG. They change in composition from basanite (BAS) in the oldest flows, to alkaline olivine basalt $(\mathrm{AOB})$ and hypersthene normative alkaline olivine basalt $(\mathrm{HyN})$ in the highest and youngest flows where the succession is complete. The sequence was erupted from vents to the south of Wolverine Creek and from a source in an upland area east from the confluence of Wolverine Creek and Yukon River. This latter center will be referred to as Wolverine east (WE). Where they are exposed in section, Wolverine sequence lava flows are composed solely of colonnade/entablature successions. Consequently, they have characteristics of type 1 and type 2 lava flows in the classification scheme of Long and Wood (1986). Curvicolumnar jointing is occasionally seen and generally occurs between entablature and vertically jointed colonnade successions. Such sequences are consistent with subaerial lava flows where the isothermal gradient parallels the surface slope of the flow. Long and Wood (1986) and
Lyle (2000) concluded that the development of entablatures in flows is associated with lava flows that traversed stream valleys: the resulting derangement of drainage brought water into contact with lava flows from above through joint systems which rapidly quenched horizons within them. This scenario is consistent with the Wolverine lava flows which followed ancestral valleys of Wolverine Creek and the Yukon River.

Eruption of the Wolverine centers began ca. 4.3 Ma during the Gilbert Reversed Chron between the Nunivak and Chochiti (normal) subchrons (Fig. 7) based upon Ar-Ar dating and reversed polarity of the stratigraphically lowest flow found. Eruptions occurred intermittently until ca. $2.98 \mathrm{Ma}$ (Table 1).

Lava flows filled the broad, pre-volcanic canyon of Wolverine Creek to a depth of up to $100 \mathrm{~m}$ and an elevation of approximately $550 \mathrm{~m}$ a.s.l (the present course of Wolverine Creek follows its ancestral course). These flows extended from west to east and flowed at least $7 \mathrm{~km}$ north to the confluence of the Yukon and Pelly rivers (Fig. 2, NCD North). The original northern extent of these lava flows is not known because they were subsequently truncated erosionally by the Yukon and Pelly rivers. Lava flows from the Wolverine eruptive centers eventually filled the Yukon River valley to a cumulative depth of $80 \mathrm{~m}$ and an elevation of $520 \mathrm{~m}$ a.s.l in the area of Ne Ch'e Ddhäwa (Fig. 4).

\subsubsection{Synchronous eruptions elsewhere in Yukon}

Mafic lava flows contemporaneous with the Wolverine eruptions have been documented at two other localities in west-central Yukon. These include a grey, vesicular olivine basalt lava flow that is 
Table 1

Radiometric ages determined on Fort Selkirk Volcanic Group and Fort Selkirk tephra.

\begin{tabular}{|c|c|c|c|c|}
\hline Age (Ma B.P.) $)^{a}$ & Eruptive sequence & MP & Method age and source & $\begin{array}{l}\text { Comments related to Figs. } 3 \text { and } 4 \\
\text { (section underlined) }\end{array}$ \\
\hline $4.34 \pm 0.06$ & Wolverine & $\mathrm{R}$ & $\mathrm{Ar}-\mathrm{Ar}$, this study & Wolverine Creek section: base \\
\hline $2.98 \pm 0.05$ & Wolverine & & As above & Wolverine Creek section: top \\
\hline $4.36 \pm 0.07$ & Wolverine & $\mathrm{R}$ & $\mathrm{Ar}-\mathrm{Ar}$ this study & $\overline{\text { Ne Ch'e Ddhäwa south, highest lava flow. Underlies }}$ \\
\hline $3.921 \pm 0.11$ & & & K-Ar, Jackson et al., 1996 & $\begin{array}{l}\text { hyaloclastites from eruption of Ne Ch'e Ddhäwa. } \mathrm{K}_{\mathrm{Ar}} \\
\text { age mistakenly attributed to site } 16 \text { in Jackson et al., } 1996 .\end{array}$ \\
\hline $3.05 \pm 0.07$ & Wolverine & $\mathrm{R}$ & $\mathrm{Ar}-\mathrm{Ar}$, this study & Ne Ch'e Ddhäwa north, highest lava flow. Underlies \\
\hline $2.362 \pm 0.055$ & & $\mathrm{R}$ & K-Ar, Jackson et al., 1996 & $\begin{array}{l}\text { pre-Reid till and overlies polagonized hyaloclastites from } \\
\text { oldest eruption of Ne Ch'e Ddhäwa. }\end{array}$ \\
\hline $3.25 \pm 0.10$ & Wolverine & $\mathrm{R}$ & Ar-Ar, Nelson, 2006 & $\begin{array}{l}\text { Ne Ch'e Ddhäwa north, middle lava flow. Overlain by a gravel } \\
\text { indicating that River flow was impeded or dammed sufficiently } \\
\text { to aggrade approximately } 40 \mathrm{~m} \text { above the lowest exposed basalt } \\
\text { flow in this area. Stratigraphically below palagonized tuff from } \\
\text { first eruption of Ne Ch'e Ddhäwa volcanic center (maximum age } \\
\text { for this eruption). }\end{array}$ \\
\hline $2.14 \pm 0.14$ & Ne Ch'e & $\mathrm{R}$ & $\mathrm{Ar}-\mathrm{Ar}$ this study & Ne Ch'e Ddhäwa summit section: ice contact flows and breccias-K- \\
\hline $2.078 \pm 0.055$ & Ddhäwa & $\mathrm{R}$ & K-Ar, Jackson et al., 1996 & $\begin{array}{l}\text { Ar age mistakenly listed as sample 260689R5 in Jackson et al., } 1996 \\
\text { and attributed to site } 18 \text {. Correct sample number } 280689 \text { R5 }\end{array}$ \\
\hline $1.83 \pm 0.03(a)$ & Fort Selkirk & $\mathrm{R}$ & $\begin{array}{l}\text { Ar-Ar, Nelson et al., } 2009 \\
\text { This study }\end{array}$ & $\begin{array}{l}\text { Mushroom section: radially arrayed colonnade, pillows, hyalloclastite } \\
\text { tuff breccia (a) base of lava flows } 1 \mathrm{~m} \text { above lower mushroom gravel }\end{array}$ \\
\hline $1.83 \pm 0.04(b)$ & & $\mathrm{N}$ & Westgate et al., 2001 & (b) $6 \mathrm{~m}$ above base of exposure (c) base of lowest flow \\
\hline $2.32 \pm 0.26(\mathrm{c})$ & & - & Westgate et al., 2001 & (d) near base of flows \\
\hline $1.60 \pm 0.16(d)$ & & $\mathrm{R}$ & K-Ar, Westgate, 1989 & \\
\hline $1.489 \pm 0.063$ & Pelly & $\mathrm{R}$ & $\mathrm{Ar}-\mathrm{Ar}$, this study & $\begin{array}{l}\text { Pelly Ranch Section: lowest exposed flow in } 145 \mathrm{~m} \text { thick succession } \\
\text { of basalt flows and breccias: statistically indistinguishable from age } \\
\text { of lowest basalt flow at base of Fossil section but this site is much } \\
\text { closer to the eruptive center. }\end{array}$ \\
\hline $1.33 \pm 0.07$ & Pelly & $\mathrm{R}$ & $\mathrm{Ar}-\mathrm{Ar}$, Nelson, 2006 & $\begin{array}{l}\text { Mushroom section: dates the youngest (uppermost) basalt flow } \\
\text { of the Pelly Sequence at. Error values overlap with } 5 \text { out of } 6 \mathrm{~K}-\mathrm{Ar} \\
\text { and } \mathrm{Ar}-\mathrm{Ar} \text { ages for lava flows in stratigraphically similar positions } \\
\text { at site } 12 \text {. }\end{array}$ \\
\hline $1.37 \pm 0.05$ & Pelly & $\mathrm{R}$ & Ar-Ar, Huscroft et al. ,2004 & Cave section: Pelly volcanic center lava flows \\
\hline $1.276 \pm 0.34$ & & & K-Ar, Jackson et al., 1996 & \\
\hline $1.35 \pm 0.08$ & & & K-Ar, Westgate, 1989 & \\
\hline $1.35 \pm 0.11$ & & & As above & \\
\hline $1.47 \pm 0.11$ & & & As above & \\
\hline $1.08 \pm 0.1$ & & & Naeser et al., 1982 & \\
\hline $1.41 \pm 0.085$ & Pelly & $\mathrm{R}$ & $\mathrm{Ar}-\mathrm{Ar}$, this study & $\begin{array}{l}\text { Fossil section: flow immediately above eolian sediments containing } \\
\text { Fort Selkirk Local Fauna }\end{array}$ \\
\hline $1.48 \pm 0.11$ & & $\mathrm{R}$ & $\begin{array}{l}\text { Weighted mean, isothermal } \\
\text { plateau fission-track ages on } \\
\text { felsic tephra (1 sigma) } \\
\text { (Westgate, 1989). }\end{array}$ & Cave section: Fort Selkirk tephra \\
\hline $0441 \pm 0.76$ & Black Creek & $\mathrm{N}$ & $\mathrm{Ar}-\mathrm{Ar}$, this study & $\begin{array}{l}\text { Tip section: previously calculated and reported as } 0.311+0.032 \mathrm{Ma} \text { in } \\
\text { Huscroft et al., } 2004\end{array}$ \\
\hline $1.597 \pm 0.074$ & $\begin{array}{l}\text { Source not } \\
\text { identified }\end{array}$ & $\mathrm{R}$ & $\mathrm{Ar}-\mathrm{Ar}$ & Base of isolated lava flow near Holbrook Creek \\
\hline
\end{tabular}

${ }^{\mathrm{a}} \mathrm{K}-\mathrm{Ar}$ and $\mathrm{Ar}-\mathrm{Ar}$ ages error values at 2 sigma.

overlain by pre-Reid drift along the canyon of Rosebud Creek in the area of the confluence of Rosebud and Grand Valley creeks $70 \mathrm{~km}$ north-northwest of Fort Selkirk (Fig. 1, RBC) and a lava flow at Fortymile Bluff along Yukon River downstream from Dawson City (Fig. 1, 40mi). The Rosebud Creek lava flow has normal polarity and an $\mathrm{Ar}-\mathrm{Ar}$ age $2.95 \pm 0.044 \mathrm{Ma}$ (formerly reported as $3.23 \pm 0.05 \mathrm{Ma}$ in Huscroft et al. (2001) but recalculated from the same analytical data using an improved algorithm). Its age and normal magnetization clearly refers this eruption to the Gauss Normal Chron, between the (reversed) Mammoth and Kaena subchrons (Fig. 7). The Fortymile Bluff flow has reversed polarity (Nelson et al., 2009) and a $\mathrm{K}-\mathrm{Ar}$ date of $3.05 \pm 0.22 \mathrm{Ma}$ (Hunt and Roddick, 1992). It is referred to the (reversed) Kaena subchron within the Gauss Normal Chron (Fig. 7).

\subsection{Ne Ch'e Ddhäwa eruptive center}

The Ne Ch'e Ddhäwa edifice (Figs. 2 and 4) was built as a result of two eruptions. The older eruption predated glaciation whereas the younger was subglacial. The older event erupted at least $50 \mathrm{~m}$ of mafic hyaloclastite tuff that has been altered to palagonite (hereafter referred to as the 'lower tuff). It filled a canyon cut into lava flows from the Wolverine eruptive centers. The lower tuff is intercalated between lava flows along its northern (downstream) margin. It rests on a magnetically reversed lava flow $\mathrm{Ar}-\mathrm{Ar}$ dated at $3.21 \pm 0.07$ (Nelson et al., 2009) and is capped by a magnetically reversed lava flow dated at $3.049 \pm 0.072 \mathrm{Ma}$ (this study). The paleomagnetism of the lower tuff has not been determined due to its alteration but its intercalation between the dated lava flows indicates that its eruption likely occurred during the normal polarity interval between the Mammoth and Kaena subchrons (Fig. 7).

The age of the eruption between ca. 3.21 and 3.05 Ma clearly predates known regional glaciation in the west-central Yukon (Duk-Rodkin et al., 2010). Consequently, glacial damming can be eliminated as a mechanism for the formation of the lake under which this hyaloclastite was erupted. Landslides large and rapid enough to dam large rivers are unlikely in a relatively low relief physiographic setting. The simplest explanation for the creation of this lake is by volcanic damming of the river. The lower tuff erupted within a canyon cut into pre-existing fill of lava flows from the 

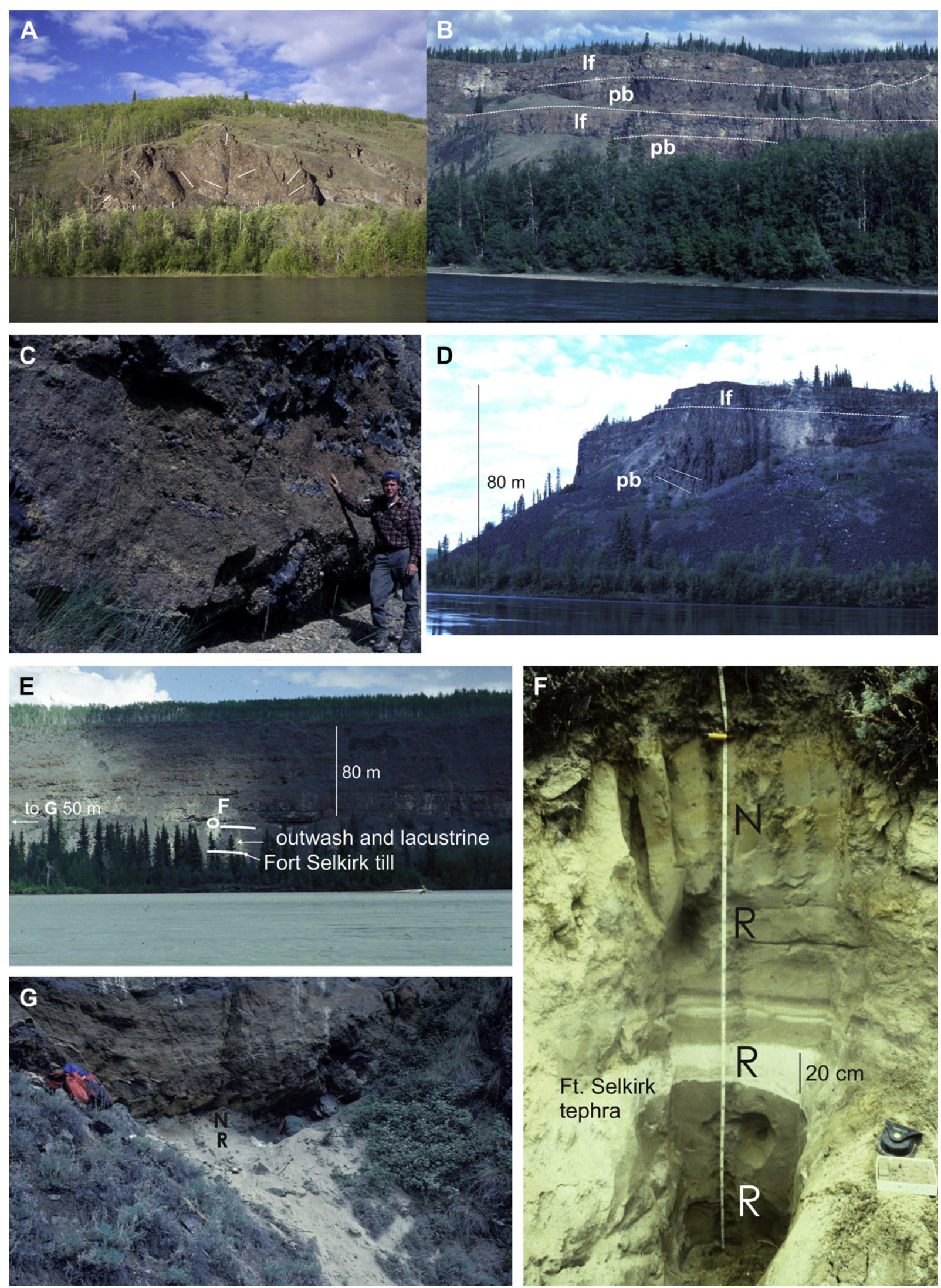

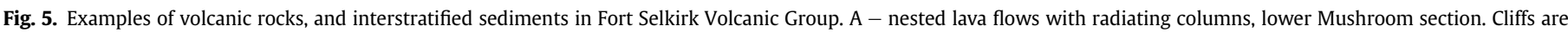

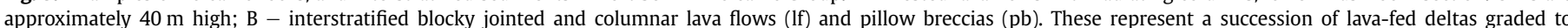

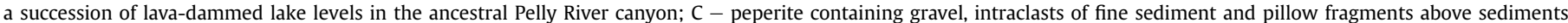

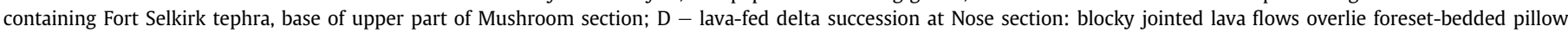

Please cite this article in press as: Jackson, L.E., Jr.et al., Pliocene and Pleistocene volcanic interaction with Cordilleran ice sheets, damming of the Yukon River and vertebrate Palaeontology, Fort Selkirk Volcanic Group, west-central Yukon, Canada, Quaternary International (2011), doi:10.1016/j.quaint.2011.08.033 


\section{Equal area projection of mean paleomagnetic data from sampled sites}
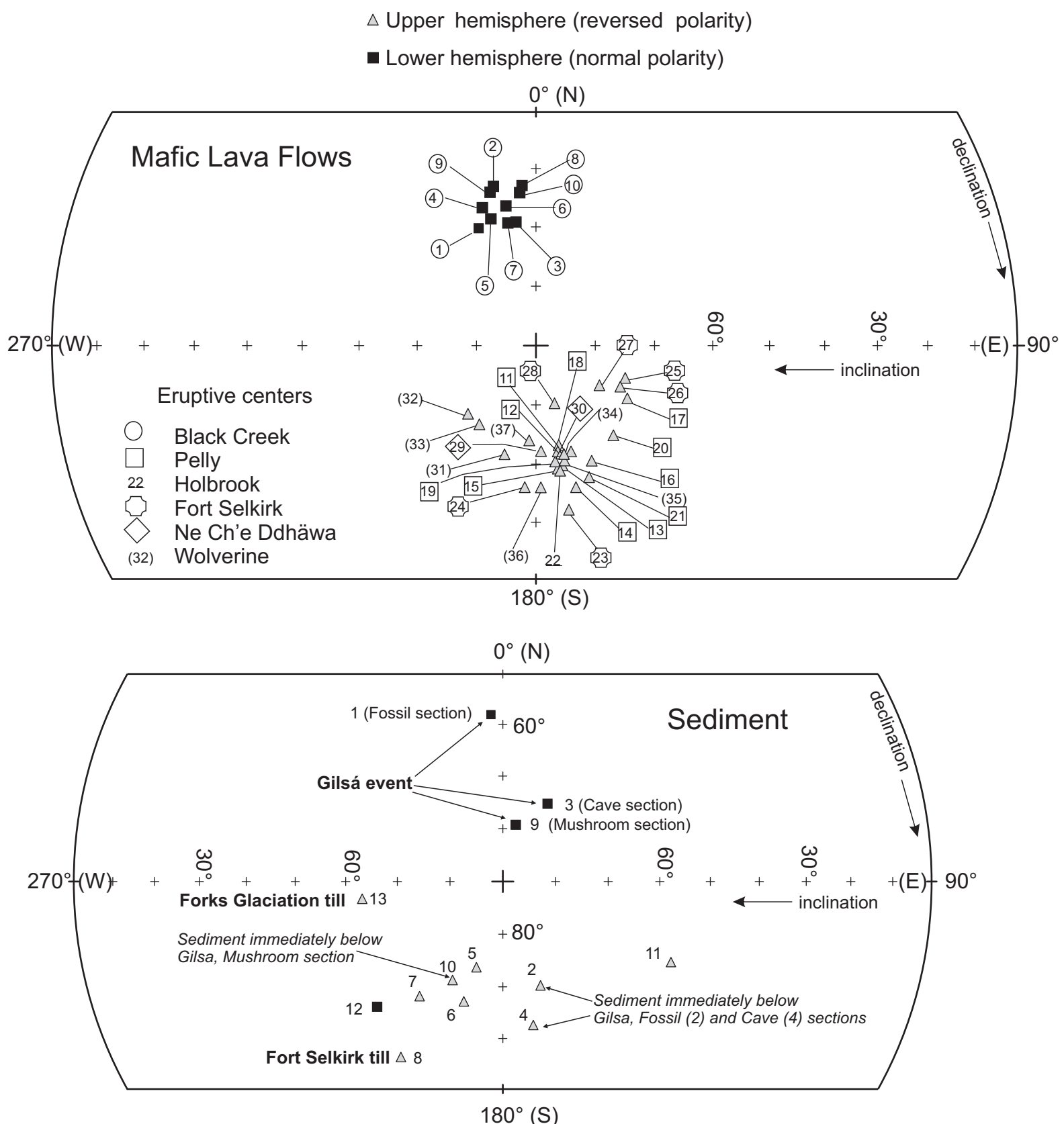

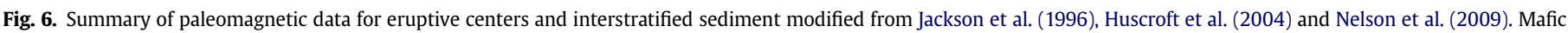

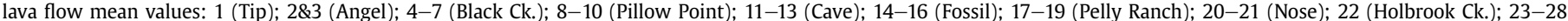

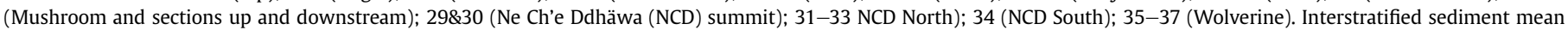

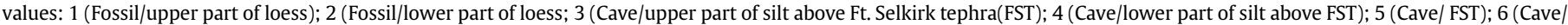

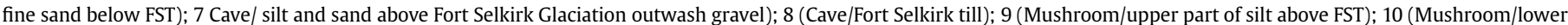
part of silt above FST); 11 (Mushroom/silt); 12 (NCD North/loess overlying till); 13 (NCD North/ till).

Wolverine eruptive centers (Fig. 4). This canyon may have been dammed by lava flows not presently visible or by the eruption of the tuff itself. By the end of the eruption of the lower tuff, the ancestral Yukon River was temporary elevated at least $40 \mathrm{~m}$ above the base of lava fill. River flow deposited a $1 \mathrm{~m}$-thick polymictic cobble and pebble gravel that lies between the 3.21 and 3.05 Ma lava flows and at the same elevation as the top of the lower tuff (Fig. 4). The gravel is composed of 80-90 percent basalt clasts (Fig. 8). The remaining non-basalt fraction is composed of felsic granitoid clasts and schist that occur in the immediate area (Fig. 2)

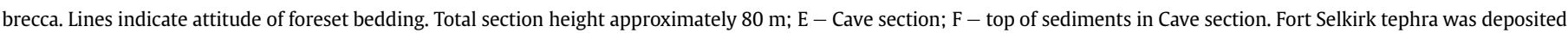

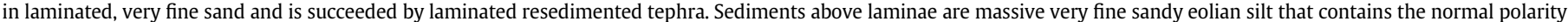

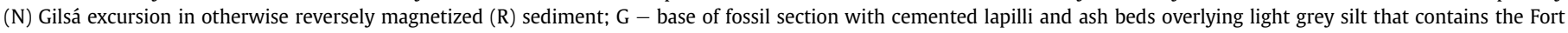
Selkirk Local Fauna. The lower part of the silt is magnetically reversed (R) and the upper is normal (N) and is referred to the Gilsá excursion. 

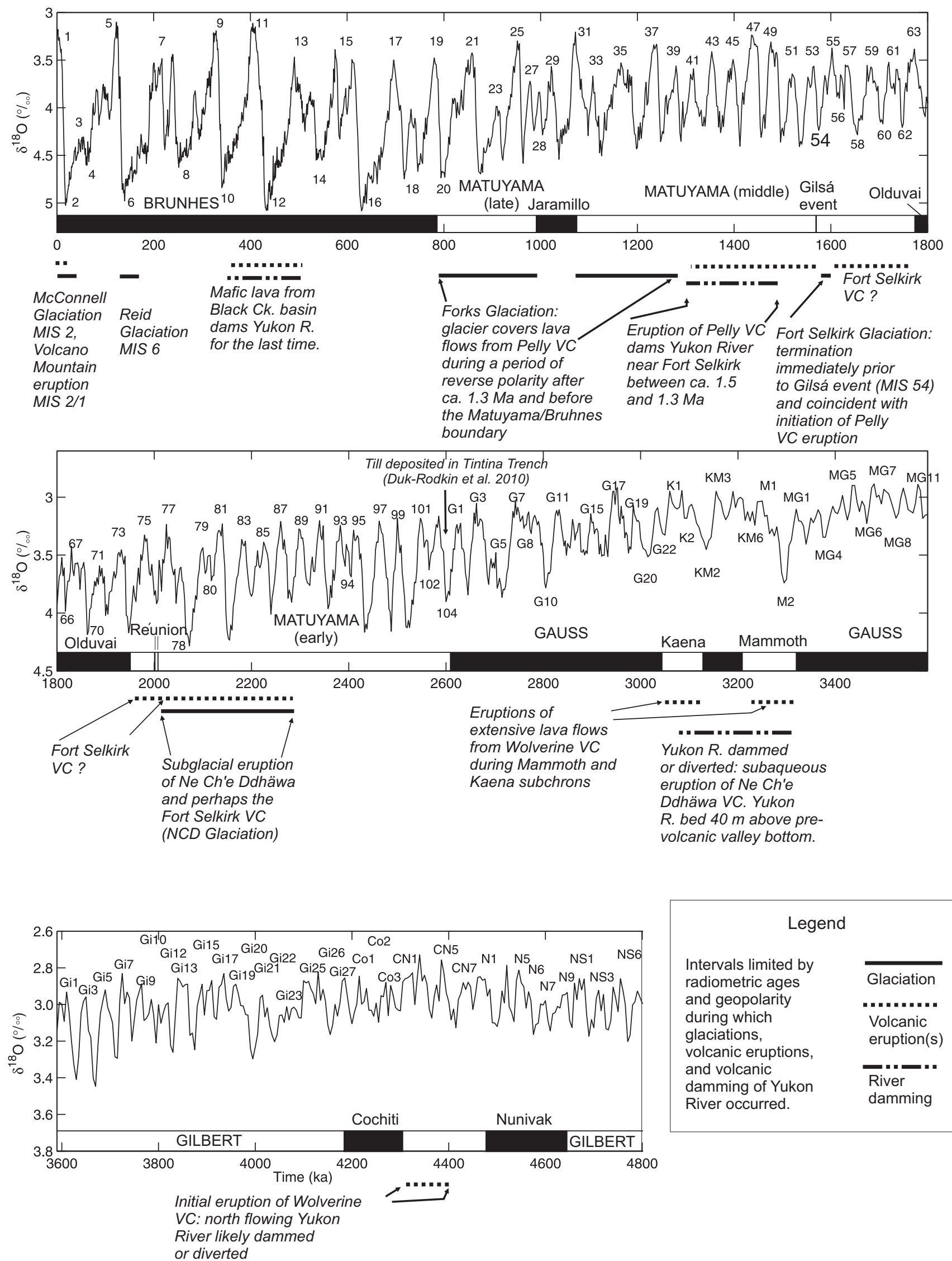

Legend

Intervals limited by radiometric ages and geopolarity during which glaciations, volcanic eruptions, and volcanic damming of Yukon River occurred.
Glaciation

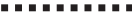

Volcanic eruption(s)

River damming

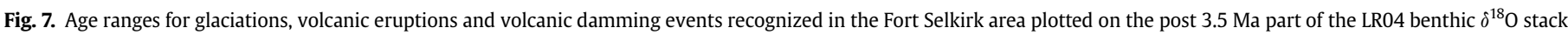
(Lisiecki and Raymo, 2005). 
Sample BCWP1 Gravel between lava flows, $\mathrm{Ne}$ Ch'e Ddhäwa north section

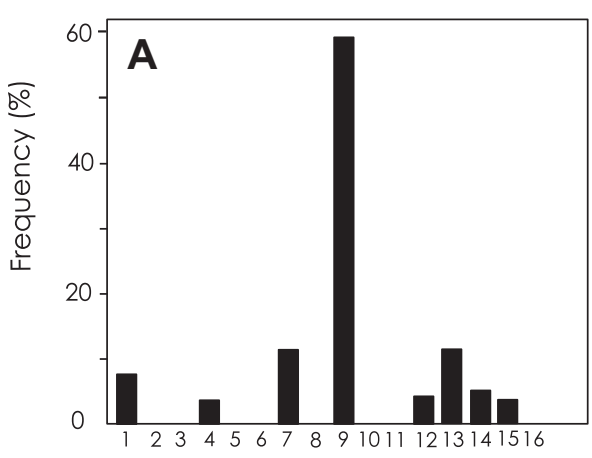

Sample 280788P1 Exotic pebbles from glaciogenic diamicton in Ne Ch'e Ddhäwa hyaloclastite

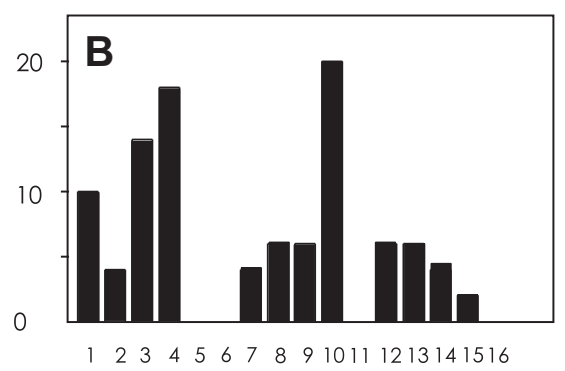

Sample 160792P1 lower Mushroom gravel

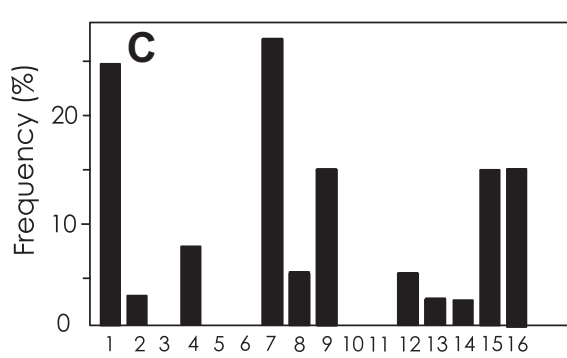

Sample 160790P1 lower Mushroom gravel

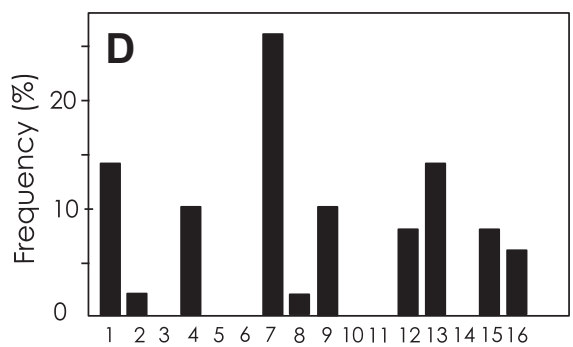

Lithology
SAMPLE 160792P3 Fort Selkirk Glaciation outwash, Mushroom section

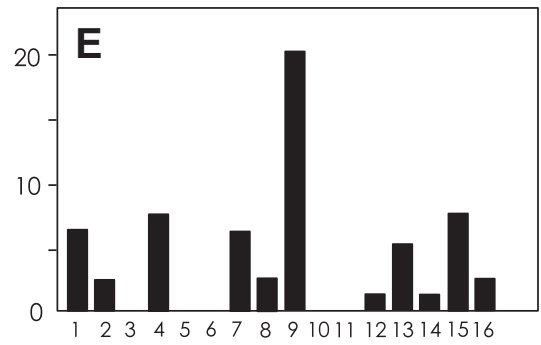

SAMPLE 170792P1 Ft. Selkirk Glaciation outwash Mushroom section

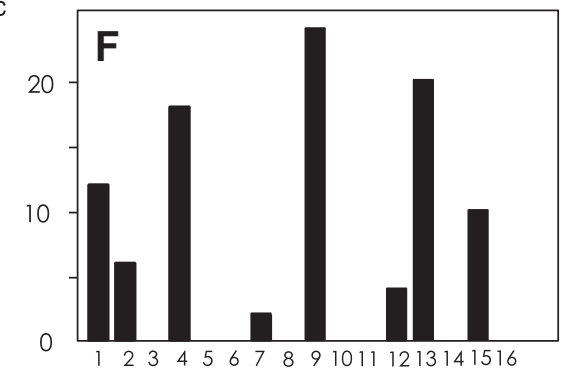

Sample 130790P1 Fort Selkirk till, Cave section

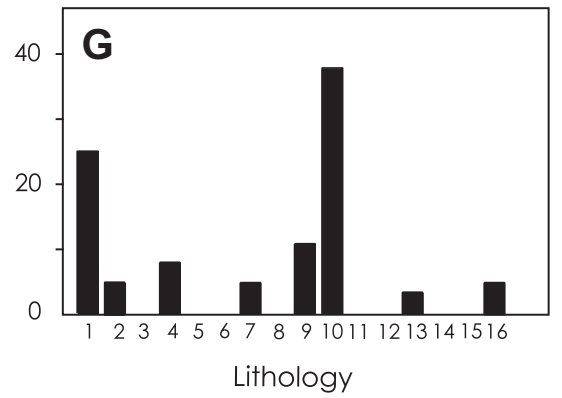

Legend

1. Sandstone and quartzite

2. Siltstone and shale

3. Feldspathic and lithic sandstone

4. Selwyn Basin chert, cherty and silicified cherty sandstone and siltstone, and chert pebble conglomerate

5. Limestone

6. Dolostone

7. Felsic and intermediate intrusives

8. Felsic and intermediate volcanics and subvolcanics

9. Basalt and basaltic subvolcanics

10. Greenstone

11. Ultramafic

12. Gneiss

13. Slate, schist, dark meta siltstone, mylonite and phyllite

14. Other metamorphics (hornfels, amphibolite)

15. Quartz and quartz-fieldspar veins

16. Unidentifiable, other.

Fig. 8. Histograms of lithologic compositions of clasts obtained from gravel and diamictons in the Fort Selkirk area. 
and quartzite and chert. The latter two lithologies crop-out extensively tens of kilometres to the east and south of the Fort Selkirk area. A few amphibolite clasts are also present. The only mapped source for amphibolite is about $3 \mathrm{~km}$ to the south of the gravel's exposure along Yukon River (Tempelman-Kluit, 1984). Thus the setting and lithology of this gravel collectively documents a fill of at least $40 \mathrm{~m}$ of hyaloclastite tuff and lava flows within Yukon River valley at the time of the deposition of this gravel by an ancestral river.

\subsubsection{Subglacial eruption of Ne Ch'e Ddhäwa}

A subsequent eruption built the Ne Ch'e Ddhäwa (NCD) volcanic edifice upon the lower tuff and adjacent lava flows. NCD rises about $300 \mathrm{~m}$ above the present flood plain of Yukon River. An extensive exposure along its western flank reveals a core of composed of a chaotic melange of tuff and pillow tuff breccia (Fig. 4). Surrounding margins are composed of bedded to massive palagonized tuff. These volcaniclastic rocks (White and Houghton, 2006) are olivine nephelinite (NEPH) in composition. The summit is comprised of pillow breccia and pillow tuff breccia that are BAS in composition (Francis and Ludden, 1990). Prominent lherzolite xenocrysts are found throughout the edifice (Sinclair et al., 1978) as well as scattered exotic pebbles and local blocks of glaciogenic diamicton (Fig. 6) (Jackson, 1989; Jackson et al., 1996). Pillows near the summit of this isolated edifice are particularly noteworthy for their content of exotic pebbles. Similar assemblages of volcaniclastic rocks have been described in subglacial mafic and intermediate volcanic edifices and lava flows elsewhere in the Canadian Cordillera (Edwards and Russell, 2002; Kelman et al., 2002) and in Iceland (Skilling, 2009). The content of exotic pebbles and glaciogenic diamicton in NCD volcaniclastic rocks further support eruption in an intraglacial environment where englacial debris came in contact with magma. However, NCD lacks a mesa-like summit characteristic of tuyas (volcanoes that emerged through a glacier (Mathews, 1947)). Rather, it is a typical subglacial mound (SGM) (Hickson et al., 1995; Hickson, 2000).

An $\mathrm{Ar}-\mathrm{Ar}$ age of $2.14 \pm 0.14$ Ma was determined on magnetically reversed glassy lava near the summit of NCD (Table 1). This corroborates a previous $\mathrm{K}-\mathrm{Ar}$ age of $2.078 \pm 0.055 \mathrm{Ma}$ on the same exposure (Jackson et al., 1996) (Hunt and Roddick, 1992). These ages date the presence of a glacier at least $300 \mathrm{~m}$ in thickness in Yukon River valley. This glacier was undoubtedly a local extension of an early northern Cordilleran Ice Sheet. Cordilleran ice sheets that affected the Fort Selkirk area had their sources in the Pelly Mountains of east-central Yukon (Fig. 1) (Jackson et al., 1991; Ward and Jackson, 1992; Duk-Rodkin, 1999). The name Ne Ch'e Ddhäwa Glaciation is proposed for the glaciation documented by the subglacial eruption of NCD. The radiometric ages for this event and the reversed polarity of the rocks place it within one of several possible even numbered (cold) marine isotope stages (MIS) 88-78 inclusive. This is the oldest glaciation for which there is direct evidence in the Fort Selkirk area. It cannot be determined if the Cordilleran ice sheet reached the limit of glaciation $55 \mathrm{~km}$ to the west along Yukon River during the Ne Ch'e Ddhäwa Glaciation. Possible evidence of a glaciation predating NCD Glaciation is discussed below in regards to the gravel that underlies lava flows from the Fort Selkirk eruptive center.

\subsection{Fort Selkirk eruptive center}

Francis and Ludden (1990) recognized evidence for a small, predominantly NEPH series eruptive center along Yukon River $4 \mathrm{~km}$ downstream of the confluence of Yukon and Pelly rivers where a complex of lava flows and pillow tuff breccia is exposed along about $500 \mathrm{~m}$ of cliff banks on the north side of the river (lower portion of the Mushroom section in Figs. 3 and 5A). An additional erosional remnant also occurs immediately south of Fort Selkirk town site (Fig. 2, star symbol). Francis and Ludden (1990) called this the Fort Selkirk eruptive center (FSEC). They suggested that the eruptive vent for FSEC was beneath the bed of Yukon River at the time of the eruption: FSEC lava flows overlie a polymictic gravel (here called the lower Mushroom gravel). This gravel is strongly imbricated and indicates the same westerly flow direction for the paleo-Yukon River along this part of its course as the contemporary Yukon River (Jackson, 2000). The lithology of this gravel is similar to gravel that is clearly glacial outwash higher in Mushroom section and in Cave section (Fig. 8). The top of this unit is about $13 \mathrm{~m}$ above the present flood plain of Yukon River (see below). Only the upper two metres of the gravel are exposed: its total thickness is unknown. The contact between lava flows and gravel is commonly marked by peperite and pillow-rich flow breccia. This suggests lava flow on or eruption within a wet gravel flood plain. FSEC lava flows and breccia are unconformably overlain by outwash gravel deposited following the retreat of glacial ice at the end of the subsequent Fort Selkirk Glaciation (Westgate et al., 2001).

FSEC lava flows are predominantly fan-columnar-jointed irregular bodies tens to a hundred metres in width and thickness. Orientations of columns range from vertical to horizontal or overturned (Fig. 5A). The columns are abruptly bounded and nested within other similar bodies. They are bounded along a nearly vertical contact by pillow tuff breccia along the downstream limit of the exposure. Fan-columnar jointing indicates a cooling history involving non-horizontal isothermal surfaces surrounding a lava flow. They have been attributed to flood water entering thick lava flows or lava flows entering standing water (Long and Wood, 1986; Lyle, 2000), and cooling within lava tubes (Lyle, 2000). They are also common in subglacial eruptive environments (Skilling, 2009: his facies lb; Roddick et al., 1977; Bergh, 1985; Bergh and Sigvaldason, 1991). Kelman (2005) and Smellie (2006) have shown that fancolumnar jointing can be produced where subglacial eruption occurs under thin, crevassed ice so that meltwater drains away and prevents the generation of hyaloclastite tuffs and breccias. However, unlike the NCD subglacial mound, exotic clasts or glaciogenic diamictites have not been found within these lava flows. A definitive explanation for the occurrence of the nested, fancolumnar-jointed bodies in this area cannot be made based upon their field relationships as they are presently understood.

\subsubsection{Age of the Fort Selkirk eruptive center (lower part of} Mushroom section)

Determination of the age of eruption or eruptions of FSEC has been problematic because of large error ranges of $\mathrm{K}-\mathrm{Ar}$ radiometric ages, conflict between a single $\mathrm{Ar}-\mathrm{Ar}$ radiometric age and remanent magnetic polarity (Table 1 ), and significant secular variation among its flows (Nelson et al., 2009) (Fig. 6).

With regard to radiometric ages, Westgate et al. (2001) reported a $\mathrm{K}-\mathrm{Ar}$ age of $2.32 \pm 0.26 \mathrm{Ma}$ (two sigma) on radially arrayed columnar basalt immediately above the lower Mushroom gravel (Fig. 3). Although remanent magnetism was not determined for the dated whole rock sample, the site was determined to have reversed polarity by Jackson et al. (1996) and Nelson et al. (2009). The error values span a range from 2.58 to ca. $2.06 \mathrm{Ma}$ (Table 1 and Fig. 7). This spans a period of reversed geopolarity during the lower part of Matuyama Chron and prior to the normal polarity Olduvai subchron. That age range includes the error ranges of the radiometric ages determined on lava from the subglacial eruption of Ne Ch'e Ddhäwa. However, Fort Selkirk lava flows from a similar stratigraphic position produced an $\mathrm{Ar}-\mathrm{Ar}$ age of $1.83 \pm 0.03 \mathrm{Ma}$ (Nelson et al., 2009). The two sigma error values of this age fall entirely within the (normal polarity) Olduvai Subchron (1.95-1.77 Ma; 
Cande and Kent, 1995). Thus, this radiometric age is incompatible with the polarity of the rock suggesting that this age may be inaccurate at the two sigma error value.

Two additional $\mathrm{K}$-Ar radiometric ages have been determined on lava flows higher within the nested lava flows from the Fort Selkirk eruptive center. These are $1.83 \pm 0.04 \mathrm{Ma}$ and $1.60 \pm 0.16 \mathrm{Ma}$ (at two sigma error values). The lava flow that yielded the former age was reported to have normal polarity and the latter reversed (Westgate et al., 2001). Nelson et al. (2009) made a concerted effort to find and resample the site with normal polarity but they were not able to corroborate it: all their measurements yielded reversed polarity. Like the $\mathrm{Ar}-\mathrm{Ar}$ age described above, the error values for the older $\mathrm{K}-\mathrm{Ar}$ age fall entirely within the normal polarity Olduvai subchron. Thus, it too would appear to be inaccurate at two sigma error value. There presently is no explanation for how the isotopic systematics may have been disrupted in these rocks in order to produce these inconsistencies. The error range for the $1.60 \mathrm{Ma}$ lava spans $1.76-1.44$ Ma which was a period of reversed geopolarity during the middle part of the Matuyama Chron. However, the portion of the error value younger than ca. $1.5 \mathrm{Ma}$ is clearly incompatible with the well dated overlying sediments and lava flows from the Pelly eruptive center and can be disregarded (see below).

In addition to the wide range of radiometric ages on these lavas, Nelson et al. (2009) found significant secular variation within FSEC flows (Fig. 7). They suggested that the FSEC lava flows are the product of several eruptions sufficiently separated in time to record significant secular variation.

In summary, the age of eruption or perhaps two or more eruptions of FSEC is poorly constrained to periods of reversed geomagnetic polarity over a range of from 2.58 to ca. 1.5 Ma.

\subsection{Volcanic activity between the eruptions of Fort Selkirk and Pelly volcanic centers}

A single $1 \mathrm{~km}$ long remnant of a reversed polarity AOB flow overlies terrace gravels $26 \mathrm{~m}$ above the north bank of the Yukon River immediately upstream from the confluence with Holbrook Creek (Fig. 2, HCF; Huscroft, 2002a,b; Huscroft et al., 2004). The underlying terrace gravel is strongly imbricated and indicates a westerly flow direction consistent with the contemporary Yukon River. An $\mathrm{Ar}-\mathrm{Ar}$ age of $1.597 \pm 0.074 \mathrm{Ma}$ was determined on the flow. This age is compatible with its reversed polarity (Fig. 7). The eruptive source of this lava flow is unknown.

\subsection{Pelly center eruptions, river damming, Fort Selkirk Glaciation and Fort Selkirk Local Fauna}

All lava flows from the Pelly eruptive center are magnetically reversed (Jackson et al., 1996; Nelson et al., 2009) and they are compositionally dominated by AOB (Francis and Ludden, 1990). $\mathrm{Ar}-\mathrm{Ar}$ and $\mathrm{K}-\mathrm{Ar}$ ages bracket eruption of the Pelly eruptive center between ca. 1.5 and ca. 1.3 Ma (Table 1). A single $\mathrm{K}-\mathrm{Ar}$ age of $1.08 \pm 0.05 \mathrm{Ma}$ (Naeser et al., 1982) indicates a more recent age for a lava flow within the Pelly sequence but this age has not been reproduced by subsequent dating and much of its error range overlaps with Jaramillo (normal polarity) subchron (Fig. 7) which brings its accuracy into question. Lava flows from the Pelly eruptive center buried much of the pre-existing topography between Pelly Ranch, Black Creek and Yukon River including lava flows and breccias and of the Fort Selkirk eruptive center. Pelly flows are separated from Fort Selkirk lava flows by till and outwash from the Fort Selkirk Glaciation and interglacial lacustrine sediments and loess (Jackson et al., 1996; Westgate et al., 2001).
The exact location(s) of the Pelly eruptive center vents (Fig. 2) is obscured by forest and muskeg north of the Yukon River. Recent high resolution aeromagnetic surveys (e.g. Kiss and Coyle, 2009) suggest an eruptive source in the upland immediately northwest of Pelly Ranch. This is corroborated by thickening of Pelly lava flows northward from the Yukon River from a cumulative thickness of about 85 along the Yukon River (Cave, Fossil and Nose sections) to a cumulative thickness of about 145 m near Pelly Ranch (Fig. 3).

Exposures of Pelly center volcanic rocks along the Yukon River are dominated by irregularly jointed entablatures with secondary vertically jointed colonnades. However, in the area of the confluence of the Yukon and Pelly rivers, eruptive faces consist of at least $50 \mathrm{~m}$ of foreset-bedded pillow breccia succeeded by flows with a colonnade-entablature internal structure (Fig. 3, Nose section). Two successions of thick pillow breccias and lava flows occur at the Pelly Ranch section. Jackson et al. (1996) suggested the succession at the confluence of the Pelly and Yukon rivers was created by lava flows entering a deep lake. This type of succession has come to be recognized as indicative of a lava-fed delta (Skilling, 2002). Alternating flows and pillow breccias in the Pelly Ranch section presumably marks a succession of lava-fed deltas that entered a successive stands of a lake or lakes created by volcanic damming of the ancestral canyon of Pelly River.

The Pelly eruptive center lavas buried successions of glacial and nonglacial sediments that are of glacial-chronologic and biochronologic significance. These are detailed below.

\subsubsection{Cave section: volcanic damming of the Yukon River}

The Cave section contains the most complete succession of sediments from the Fort Selkirk Glaciation. It also records the deposition of lacustrine sediments as a result of the initial damming of the Yukon River by lava flows from the Pelly eruptive center.

The reversed polarity Fort Selkirk till (Figs. 3 and 6) directly overlies Triassic age greenstone at the base of Cave section. Till is overlain by magnetically reversed polymictic outwash gravel (Nelson et al., 2009). This grades upward into finely bedded sand and silt which includes the Fort Selkirk tephra. The sediments show no evidence of soils, cryoturbation or other indications of protracted breaks in sedimentation. The top of this fining-upward sequence is about $35 \mathrm{~m}$ above the flood plain of the present Yukon River. A similar succession, but without till, is present at the Mushroom section. Maximum limiting ages for the till, outwash and succeeding stratified sand and silt come from the underlying Fort Selkirk eruptive center lava flows in the Mushroom section with radiometric ages as young as ca. 1.6 Ma. Minimum ages for this sequence are limited by fission-track ages on the Fort Selkirk tephra (weighted mean, isothermal plateau fission-track ages $1.48 \pm 0.11$ Ma Westgate et al. 2001) and radiometric ages of overlying Pelly eruptive center lava flows.

Equally significant, a magnetic reversal (reversed to normal) occurs within the upper $1 \mathrm{~m}$ of sediment in Cave and Mushroom sections. The magnetic reversal is underlain in these sections by the magnetically reversed Fort Selkirk tephra and overlain by magnetically reversed lava flows with ages of $1.37 \pm 0.05$, $1.276 \pm 0.34,1.35 \pm 0.16,1.35 \pm 0.22$, and $1.47 \pm 0.22 \mathrm{Ma}$ (Table 1 ). This magnetic reversal has been assigned to the short lived Gilsá polarity excursion (Clement and Kent, 1987; Udagawa et al., 1999) on the basis of this radiometric age control (Froese et al., 2001; Nelson et al., 2009). This will be referred simply as the Gilsá excursion.

The fining-upward sedimentary sequence (including the Fort Selkirk tephra) at Cave section is overlain by up to a metre of a mixture of vesicular basalt fragments, non-volcanic pebbly sand and pebble gravel, and charred fossil wood (Westgate et al., 2001; 
Huscroft, 2002a,b). At Mushroom section, the contact is a consolidated, chaotic mixture of sand and fluvial gravel intraclasts, and pillow fragments in a matrix of fine volcanoclastic lapilli which is up to $3 \mathrm{~m}$ in thickness.

Intermixtures of volcanoclastic and non-volcanic clastic sediments are typically formed by fragmentation of magma as a result of effusion and intermingling of wet sediment and are referred to as peperite (Williams and McBirney, 1979; Skilling, 2002; White and Houghton, 2006). At Cave section, the peperite appears to be locally mixed with lapilli and ash similar to that at the base of Fossil section (see discussion of Fossil section below). At Cave and Mushroom, peperite is succeeded by pillow breccia, followed by up to $45 \mathrm{~m}$ of subaerial basalt flows from the Pelly eruptive center.

The stratigraphic sequence of outwash gravel succeeded by slack water sediments, peperite, and pillow breccia suggests that local base level in the Yukon valley immediately downstream from the Cave section was progressively rising following retreat of ice from the area. This culminated with slack water conditions developing $35 \mathrm{~m}$ above the contemporary flood plain of the Yukon River rather than incision of the glacial sedimentary fill that would be expected following the retreat of a valley glacier. Lava flows from the Pelly eruptive center entered this slack water and mingled with saturated sediments to form peperite and overlying pillow breccia at Cave section.

The mechanism of base level rise was apparently filling and damming of the Yukon valley by lava flows from the Pelly eruptive center immediately downstream from the Cave section. The lava flow and pillow breccia at the base of Fossil section $200 \mathrm{~m}$ downstream (see below) were a part of this lava fill. Lava flows from the Pelly center eventually inundated the areas of the Fossil, Cave and Mushroom sections and finally reached the area of the present confluence of Yukon and Pelly rivers (Fig. 3 Nose section). The resulting lake would have flooded an extensive reach of the Yukon River valley upstream: assuming the $42 \mathrm{~cm} / \mathrm{km}$ gradient that characterises the modern Yukon River (Shimamura et al., 2000), a lava dam $70 \mathrm{~m}$ high at Nose section would have created a lake extending about $170 \mathrm{~km}$ to the south.

The Victoria Rock area, immediately downstream from the Fort Selkirk town site (Fig. 2), marks the narrowest width of the Yukon River valley between country rock to south and basaltic palisades to the north. The narrows between cliff banks marks the site of the breached lava dam created by the Pelly eruptive center's eruptions at the time of cessation of Pelly volcanism ca. 1.3 Ma ago.

\subsubsection{Refinement of the age of Fort Selkirk Glaciation}

Nelson et al. (2009) concluded that the Fort Selkirk Glaciation occurred between the end of the Olduvai Subchron and the Gilsá excursion on the basis of bracketing radiometric ages and reverse remanent magnetism of the Fort Selkirk till and overlying sandy sediments. Therefore, the Cave section sediments can be correlated to MIS $54(1.585-1.570 \mathrm{Ma})$ of the conservatively tuned LR04 benthic $\delta^{18} \mathrm{O}$ stack of 57 marine cores (Lisiecki and Raymo, 2005): the Gilsá excursion is well dated to MIS 54 based upon marine stratigraphy in the North Atlantic Ocean and loess/soil stratigraphy in northern China (Channell et al., 2002; Yang et al., 2007). The sediments that record the Gilsá excursion at Cave section are at the top of a conformable vertical succession from till to outwash to slack water sediments. Based upon this, the Fort Selkirk Glaciation is referred to MIS 54 as well: there is no evidence of any hiatus in deposition within Cave section significant enough to place the Fort Selkirk Till within an earlier cold peak of the MIS record.

The Fort Selkirk Glaciation clearly occurred during ca. $41 \mathrm{ka}$ warm/cold global climatic cycles that characterized the late Pliocene and early Pleistocene (Lisiecki and Raymo, 2007) prior to the establishment of the orbital eccentricity-dominated (100 ky) climatic cycles that have dominated approximately the last $1 \mathrm{Ma}$ (Ashkenazy and Tziperman, 2004). Had the Fort Selkirk Glaciation occurred during a preceding cold peak preceding MIS 54, the time for erosion, pedogenesis or other processes to affect these erodible sediments would have been at least $50 \mathrm{ka}$ or longer. There is no evidence of a break in sedimentation of such duration within this erodible fining-upward succession.

These findings corroborate the suggested age of the Fort Selkirk Glaciation at ca. 1.5 Ma by Westgate et al. (2001) based upon their correlation of outwash that closely underlies the $1.45 \pm 0.14 \mathrm{Ma}$ Mosquito Creek tephra at the Midnight Dome terrace near Dawson City to the Fort Selkirk till.

\subsubsection{Fossil Section: age of Fort Selkirk Local Fauna and implications for the age of Cape Deceit Fauna (Alaska)}

An $8 \mathrm{~m}$ thick reversed polarity vesicular basaltic lava flow $(1.41 \pm 0.085 \mathrm{Ma})$ occurs at the base of Fossil section (Fig. 3 ). The lava flow and $50 \mathrm{~cm}$ of flow breccia overlie $2 \mathrm{~m}$ of bedded $(2-10 \mathrm{~cm}$ in thickness) mafic vesicular lapilli and ash partially lithified by a ferruginous cementation. Individual spindle-shaped vesicular pyroclasts are present within lapilli beds. Ash and lapilli beds contain syndepositional slump structures where they accumulated from air-fall on steep irregular bedrock topography. Thus, this bedded mafic tephra records a pyroclastic eruption that preceded the inundation of the area by lava flows from the Pelly eruptive center.

The bedded tephra overlies and preserves a structureless eolian silt that contains the Fort Selkirk Local Fauna (FSLF) (Storer, 2003, 2004). The fossiliferous silt comprises a lens up to $1.5 \mathrm{~m}$ thick and about $5 \mathrm{~m}$ long (Fig. 5). It accumulated on greenstone bedrock and contains angular talus fragments up to $20 \mathrm{~cm}$ long. The silt lens fills a depression at the base of a greenstone cliff (now buried under lava flows). Degraded plant fragments and wood occur along the contact between mafic lapilli and eolian silt. This and the presence of bat remains in FSLF infer that the area was within the northern limit of forest (Parker et al., 1997) at the time of deposition of the eolian silt.

The lower half of the silt is reversely magnetized while the upper half is normal (Jackson et al., 1996; Fig. 6). FSLF includes abundant cheek teeth of the fossil vole Microtis deceitensis, whose anteriormost lower molar is characterized by a four-triangle dental crown pattern. The type sample of $M$. deceitensis is from the extensively studied Cape Deceit Fauna (CDF) in Alaska (Guthrie and Matthews, 1971; Matthews, 1974) which contains one of the oldest records of cold adapted Arctic Ocean borderland biota in North America. CDF was previously assigned to the late Pliocene or early Pleistocene, and lies within normal polarity sediment (BrighamGrette and Hopkins, 1991). Storer (2003) maintained that $M$. deceitensis at Fossil section was significantly younger than $M$. deceitensis in CDF due to its relatively more complex dentition. Furthermore, a single tooth of Microtus sp. of the "North American clade" (Bell and Bever, 2006), whose anterior lower molars have a five triangle crown pattern, was recovered at Fossil section: its appearance post dates CDF in the fossil record and is the earliest known occurrence of the group in eastern Beringia (the fossil is shown in Storer, 2003, Fig. 4, No.11). The magnetic reversal at Fossil section is assigned to the Gilsá excursion based upon the radiometric age and reversed polarity of the overlying mafic lava flow and similar stratigraphic succession of normally magnetized sediments preserved at the base of lava flows from the Pelly eruptive center at the Cave (200 m east and at about the same elevation) and Mushroom sections (see above). Although the Fort Selkirk tephra, which occurs at the Cave and Mushroom sections, does not occur at Fossil section, there is paleontological evidence that supports the correlation of sediments at Fossil section to those at the top of the sediments in Cave section: scattered teeth originally referred to 
Lasiopodomys sp. were found in the sediments at Cave (Jackson et al., 1996). That designation by R. Harington of the Canadian Museum of Nature followed the taxonomy of Repenning and Brouwers (1992), who assigned $M$. deceitensis to the genus Lasiopodomys. This is in agreement with the conclusion of Storer (2003) that the normally magnetized sediments that host the CDF are older that those at Fossil. This assigns CDF to the Olduvai subchron or an older period of normal geomagnetic polarity. It further eliminates the possibility that CDF dates to the younger Jaramillo subchron in the latter part of the Matuyama Chron as was favoured by Brigham-Grette and Hopkins (1991).

\subsection{Forks Glaciation}

One or more advances of glacial ice into or beyond the Fort Selkirk area occurred after the cessation of volcanism from the Pelly eruptive center. Bostock (1966, p. 5) described drift overlying lava flows northwest of Fort Selkirk. Drift cover was noted in this area: a discontinuous veneer of polymictic gravel at the top of Nose Section and erratic pebbles including chert pebbles from the Selwyn basin directly north of Fort Selkirk. Furthermore, fluting and striations on basalt flows were recorded by Bostock (1966, p. 5) near Pelly Ranch (ca. UTM 380350 N, $6967950 \mathrm{E}$ ). Unfortunately, orientations of striations and flutes were not reported by him. The name 'Forks Glaciation' is assigned to one or more glacial advances into or beyond the Fort Selkirk area following the termination of eruptions from the Pelly volcanic center and prior to the middle Pleistocene Reid Glaciation (Huscroft et al., 2004; Ward et al., 2008). The name 'Forks' is eponymous from the historic name 'the forks' given to the confluence of Yukon and Pelly rivers by Hudson Bay Company explorer and trader, Robert Campbell who built the original Fort Selkirk there in 1848 .

A till with reversed magnetic polarity caps the Ne Ch'e Ddhäwa north section (NCDN) immediately south of the confluence of Yukon and Pelly rivers (Nelson, 2006; Nelson et al., 2009) (Figs. 4 and 6). Jackson (2000) had referred this till to the middle Pleistocene Reid Glaciation. On this basis, he concluded that glacier ice reached the confluence of the Yukon and Pelly rivers during Reid Glaciation. The subsequent discovery that this till has reversed polarity indicates that the limit of ice during Reid Glaciation (which clearly occurred during the present Brunhes Chron) was farther upstream. The local limit of glacial ice during Reid Glaciation is near the mouth of Wolverine Creek as initially suggested by Bostock (1966) (Fig. 2).

The till capping NCDN documents the last glacier to reach the confluence of the Yukon and Pelly rivers. This occurred during the Matuyama Chron based upon its magnetic polarity and field relationships with the radiometrically dated underlying basalt flows and the Ne Ch'e Ddhäwa subglacial mound. The preservation of reversed magnetism in this till precludes overrunning of it by glaciers during the subsequent Bruhnes Chron. A glacial advance extensive enough to deposit the till at NCDN would likely have reached the Pelly flows at the Nose Section or have been responsible for the deposition of proglacial gravel that caps that section. Further, based on glacial flow patterns reconstructed from subsequent glaciations, valley glaciers descending the Yukon River valley from past Cordilleran ice sheets would be as extensive as those descending the Pelly River valley. Consequently, it would be unlikely that a valley glacier descending the Pelly River would inundate Pelly Center lava flows without a glacier from the Yukon River valley affecting them as well. Thus, the Forks Glaciation is assigned to an interval of the late Matuyama Chron after the termination of the eruption Pelly eruptive center ca. $1.3 \mathrm{Ma}$ and prior to Matuyama/Brunhes magnetic reversal ca. $0.78 \mathrm{Ma}$ (Fig. 7).

\subsection{Damming of the Yukon River by the middle Pleistocene Black Creek eruption}

Francis and Ludden (1990) included the AOB flows downstream from the confluence of Black Creek and Yukon River within the Pelly eruptive center lava flows. However, Huscroft (2002a,b) and Huscroft et al. (2004) determined that they were the product of a significantly younger period of eruption based upon their normal remanent magnetization and an $\mathrm{Ar}-\mathrm{Ar}$ age of $311 \pm 32 \mathrm{ka}$. This age has subsequently been recalculated from the same analytical data to $441 \pm 76 \mathrm{ka}$ (MIS 13-10). Outwash overlies the lower reaches of this lava flow. This outwash can be traced upstream to the area of to the terminus of the valley glacier that descended Yukon River valley from the margin of a cordilleran ice sheet during Reid Glaciation. Consequently, this radiometric age is a maximum age for Reid Glaciation (Huscroft et al., 2004). The source of these flows has not been precisely located but its general location was west of present day Volcano Mountain (Jackson and Stevens, 1992) in the basin of Black Creek: lava flowed down the valley presently occupied by Black Creek from this area. The outpouring of lava was sufficiently rapid and voluminous to dam the Yukon River in the area of the Black Creek confluence. The distribution of subaerial lava flows and pillow breccia is asymmetric with respect to the Black Creek/Yukon River confluence. A lava-fed-delta-sequence of flows over a pillow breccia complex is exposed immediately upstream from the Black Creek confluence (Fig. 3: Pillow Point) but subaerial flows extend $7 \mathrm{~km}$ downstream from this area (Figs. 2 and 3: Angel and Tip sections). This is analogous to the asymmetric pattern between lava dam facies and downstream subaerial lava flow extent within the Pelly lavas at the confluence of Pelly River with Yukon River. It is also analogous to volcanic facies seen in former lava dams along the Colorado and Nass rivers (Hamblin, 1994; Hickson and Edwards, 2001; Fenton et al., 2002).

Sporadic volcanism continued in the Black Creek basin at Volcano Mountain as recently as ca. the Pleistocene/Holocene boundary based on radiocarbon dating of organic material in piston cores from lava-dammed lakes and the presence of Holocene Brunisols developed on lapilli (Jackson and Stevens, 1992; Sanborn, 2010).

\section{Comparison of the glacial record in the Fort Selkirk area to the Dawson City and adjacent Tintina Trench}

A periglacial climate was established in west-central Yukon as early as $3 \mathrm{Ma}$ based upon the fission-track dating of the Quartz Creek tephra which partly fills an ice-wedge pseudomorph in the valley of its eponymous creek (Sandhu et al., 2001; Westgate and Froese, 2005). The oldest glacial outwash in west-central Yukon (Klondike Gravel) was reported by Froese et al. (2000) near the confluence of Yukon and Klondike rivers near Dawson City. They assigned the most extensive glaciation of the region to the Gauss Chron (ca. 2.9-2.7 Ma; MIS G20 to G-2). Duk-Rodkin et al. (2001, 2004, 2010) found analogous evidence for the most extensive glaciation of that region within complexes of graben-filling sediments in Tintina Trench to the northwest of Dawson City which they have named 'West Tintina Trench Allogroup'. These sediments were deposited by valley glaciers from the Olgilvie Mountains and early cordilleran ice sheets. The oldest deposits were referred to the initial and apparently most extensive glaciation to impact the area, which they assigned to the Gauss Chron (ca. 2.7 Ma) based on their normal remanent magnetism, interstratified paleosols, palynology, and resulting reorganization of drainage with the ancestral Yukon River basin.

The absence of unequivocal evidence for glaciations older than Ne Ch'e Ddhäwa Glaciation in the Fort Selkirk area, is likely due to 
lack of preservation of glacial sediments by lava flows: there was an apparent hiatus in volcanism between ca. 3.0 and $2.3 \mathrm{Ma}$, so that erosion likely removed any glacial deposits laid down during that time period. Only the polymictic nature of the lower Mushroom gravel described above suggests that a regional glaciation may have predated Ne Ch'e Ddhäwa Glaciation.

\section{Summary and conclusions}

The volcanic and glacial stratigraphy of the Fort Selkirk area is revised through incorporation of new and revised $\mathrm{Ar}-\mathrm{Ar}$ ages determined on mafic volcanic rocks assigned to the geomagnetic polarity timescale. Glacial and nonglacial sediments are bracketed by dated lava flows, tephrochronology and magnetostratigraphy, and they are assigned to the LR 04 composite marine isotopic record.

Neogene volcanism around the Fort Selkirk area began in the Wolverine Creek area ca. 4.3 Ma and persisted to ca. 3.0 Ma. Subaerial lava flows descended into an ancestral valley which flowed in the same direction as the present day Yukon River. At least $40 \mathrm{~m}$ of lava flows accumulated within the valley. Activity at the Ne Ch'e Ddhäwa eruptive center overlapped with the last stages of the Wolverine Creek eruptive centers. It began with a subaqueous eruption of hyaloclastic tuff between 3.21 and 3.05 Ma. This eruption caused or was coincident with volcanic damming of the paleo-Yukon River.

The first clearly demonstrable incursion of a cordilleran ice sheet into the Fort Selkirk area (Ne Ch'e Ddhäwa Glaciation) was coincident with a second eruption of the Ne Ch'e Ddhäwa eruptive center ca. 2.1 Ma. This eruption built the Ne Ch'e Ddhäwa subglacial mound within at least $300 \mathrm{~m}$ of glacial ice.

The age of the eruption(s) of nested, radially jointed lavas from the Fort Selkirk eruptive center is poorly constrained due to contradictory radiometric ages of lava flows, and discrepancies between radiometric ages and polarity data. The Fort Selkirk center erupted during a period or periods of reversed geomagnetic polarity between ca. 2.5 and $1.5 \mathrm{Ma}$.

Incursion of glacial ice into the Fort Selkirk area during the subsequent Fort Selkirk Glaciation is documented by till and outwash preserved between complexes of magnetically reversed and radiometrically dated lava flows. Sediments deposited during Fort Selkirk Glaciation grade upward into lacustrine and eolian sediments that contain Fort Selkirk tephra (fission track dated at ca. 1.5 Ma). These nonglacial sediments also preserve a short magnetic polarity reversal (reversed to normal) identified as the Gilsá polarity excursion. These temporal controls constrain the Fort Selkirk Glaciation to MIS 54. The Fort Selkirk Local Fauna, among the oldest assemblages of cold adapted Arctic Ocean borderland fauna in North America, was also coincident with the Gilsá excursion. Evolutionary changes noted within microtine rodent teeth present in the Fort Selkirk Local fauna indicate it to be younger than the Cape Deceit Fauna in Alaska.

Rapid and extensive eruption of the Pelly eruptive center filled the Yukon River valley with $70 \mathrm{~m}$ of lava flows and dammed the Yukon River. A lava-fed delta was built into this lake. Local striations and erratic pebbles occur on top of this lava fill. They and a till along the northern end of Ne Ch'e Ddhäwa document a subsequent incursion of glacial ice. The name 'Forks Glaciation' is proposed for this event. It is assigned to the last $500 \mathrm{ka}$ of the Matuyama Chron (excluding the Jaramillo normal subchron) based upon the radiometric age of ca. $1.3 \mathrm{Ma}$ for Pelly eruptive center and a reversely magnetized till associated with this glaciation.

The last major eruption occurred in the middle Pleistocene west of present day Volcano Mountain in the basin of Black Creek: lava flowed down the valley presently occupied by Black Creek from this area. The outpouring of lava was sufficiently rapid and voluminous to dam the Yukon River in the area of the Black Creek confluence. This eruption predated Reid Glaciation. Subsequent minor eruptions have occurred at Volcano Mountain as recently as ca. the Pleistocene/Holocene boundary.

\section{Acknowledgments}

The authors gratefully acknowledge collaborative work by Craig Hart and at least 10 dedicated field assistants since investigation of the late Cenozoic geology of the Fort Selkirk area began by this group in 1988. Logistical support by the Yukon Geological Survey and residents of Pelly Ranch, and the Selkirk First Nation are also gratefully acknowledged. We also acknowledge thoughtful reviews by Duane Froese and Jeff Bond. The paper was improved thanks to their efforts.

We dedicate this paper to the memory of Dr. Johan (John) F. Dormaar (1930-2010), friend, colleague, and pioneer investigator of fossil soils in western Canada.

\section{Appendix 1. Lower Mushroom gravel}

The polymictic lower Mushroom gravel (LMG) underlies the basal lava flow at Mushroom section. Only the upper $1 \mathrm{~m}$ of this gravel is exposed. Its contact with the overlying lava flow is about $13 \mathrm{~m}$ above the contemporary flood plain of the Yukon River (the base of unit is not visible). LMG has a strongly imbricated fabric that indicates a westerly flow (the same as present at this location) for Yukon River (Jackson, 2000). Collectively, it documents that the contemporary flow direction of Yukon existed at the time of its deposition and that no more than $20 \mathrm{~m}$ of net incision by Yukon River since that time.

Lithologies of the clasts composing the lower Mushroom gravel (Fig. 8, histograms B and C) are similar to those found in till, outwash gravel and hyaloclastite of the Ne Ch'e Ddhäwa, Fort Selkirk and Forks glaciations in the Fort Selkirk area (Fig. 7, histograms $\mathrm{D}$ to $\mathrm{H}$ ). It is dominated by quartzite, sandstone, siltstone, chert and cherty clastics, from the Selwyn Basin and felsic volcanics originating along the Tintina Trench at least $80 \mathrm{~km}$ to the east and northeast (Jackson et al., 1986): it contains only a secondary content of local lithologies such as felsic and intermediate plutonic rocks, schist and greenstone, Ice sheets that have advanced into the Fort Selkirk area habitually traverse much of southern Yukon from the same source areas (Duk-Rodkin, 1999). This gravel is interpreted as glacial or paraglacial i.e. reflecting erosion of a previously glaciated landscape (Church and Ryder, 1972). It differs markedly from true pre-glacial gravel in west-central Yukon, such as the auriferous White Channel gravel near Dawson City (Froese et al., 2000) that reflect erosion of a deeply weathered landscape and are dominated by quartzose and local lithologies resistant to chemical weathering.

\section{References}

Ashkenazy, Y., Tziperman, E., 2004. Are the 41 kyr glacial oscillations a 41 kyr linear response to Milankovitch forcing? Quaternary Science Reviews 23, 1879-1890.

Bell, C.J., Bever, G.S., 2006. Description and significance of the Microtus (Rodentia: Arvicolinae) from the type Irvington fauna, Alameda County, California. Journal of Vertebrate Paleontology 26, 371-380.

Bergh, S.G., 1985. Structure, Depositional Environment and Mode of Emplacement of Basaltic Hyaloclastites and Related Lavas and Sedimentary Rocks: PlioPleistocene of the Eastern Volcanic Rift Zone, Southern Iceland. Nordic Volcanological Institute, 8502, University of Iceland, Reykjavik, p. 85.

Bergh, S.G., Sigvaldason, G.E., 1991. Pleistocene mass-flow deposits of basaltic hyaloclastites on a shallow submarine shelf, South Iceland. Bulletin of Volcanology 53, 597-611.

Brigham-Grette, J., Hopkins, D., 1991. The first paleomagnetic evidence from Cape Deceit: a critical late Pliocene-early Pliocene mammal, plant macrofossil, and 
beetle locality, in central Beringia. Geological Society of America abstracts with programs, A99.

Bostock, H.S., 1936. Carmacks District, Yukon. Geological Survey of Canada, Memoir 189, p. 58.

Bostock, H.S., 1966. Notes on Glaciation in Central Yukon Territory. Geological Survey of Canada, Paper 65-56, p. 18.

Cande, S.C., Kent, D.V., 1995. Revised calibration of the geomagnetic polarity timescale for the Late Cretaceous and Cenozoic. Journal of Geophysical Research 100 (B4), 6093-6095.

Channell, J.E.T., Mazaud, A., Sullivan, P., Turner, S., Raymo, M.E., 2002. Geomagnetic excursions and paleointensities in the Matuyama Chron at Ocean Drilling Program sites 983 and 984 (Iceland Basin). Journal of Geophysical Research 107, 2114. doi:10.1029/2001JB000491.

Church, M., Ryder, J.M., 1972. Paraglacial sedimentation: a consideration of fluvial processes conditioned by glaciation. Geological Society of America Bulletin 83, 3059-3072.

Clement, B.M., Kent, D.V., 1987. Short polarity intervals within the Matuyama: transitional field records from hydraulic piston cored sediments from the north Atlantic. Earth and Planetary Science Letters 81, 253-264.

Duk-Rodkin, A., 1999. Glacial limits of Yukon Territory. In: Gordey, S.P., Makepeace, A.J. (Eds.), Yukon Digital Geology. Geological Survey of Canada Open File 3826.

Duk-Rodkin, A., Barendregt, R.W., White, J.M., Singhroy, V.H., 2001. Geologic evolution of the Yukon River: implications for placer gold. Quaternary International 82, 5-31.

Duk-Rodkin, A., Barendregt, R.W., Froese, D.G., Weber, F., Enkin, R., Smith, I.R., Zazula, G.D., Waters, P., Klassen, R., 2004. Timing and extent of Plio-Pleistocene glaciations in north-western Canada and east-central Alaska. In: Ehlersx, J., Gibbard, P.L. (Eds.), Quaternary Glaciations - Extent and Chronology, Part II. Elsevier, pp. 313-345.

Duk-Rodkin, A., Barendregt, R.W., White, J.M., 2010. An extensive late Cenozoic terrestrial record of multiple glaciations preserved in the Tintina Trench of west-central Yukon: stratigraphy, paleomagnetism, paleosols, and pollen. Canadian Journal of Earth Science 47, 1003-1028.

Edwards, B.R., Russell, J.K., 2002. Glacial influences on morphology and eruptive products of Hoodoo Mountain volcano, Canada. In: Smellie, J.L., Chapman, M.G. (Eds.), Volcano-Ice Interactions on Earth and Mars. Geological Society Special Publication 202, pp. 179-194.

Fenton, C.R., Webb, R.H., Cerling, T.E., Poreda, R.J., Nash, B.P., 2002. Cosmogenic ${ }^{3} \mathrm{He}$ Ages and Geochemical discrimination of lava-dam out-burst-flood deposits in western Grand Canyon, Arizona. In: House, P.K., Webb, R.H., Baker, V.R., Levish, D.R. (Eds.), Paleoflood Hydrology. American Geophysical Union, pp. 191-215.

Francis, D., Ludden, J., 1990. The mantle source for olivine nephelinite, basinite and alkaline olivine basalt at Fort Selkirk, Yukon. Journal of Petrology 31, 371-400.

Froese, D.G., Barendegt, R.W., Enkin, R.J., Baker, J., 2000. Paleomagnetic evidence for multiple Late Pliocene-Early Pleistocene glaciations in the Klondike area, Yukon Territory. Canadian Journal of Earth Sciences 37, 863-867.

Froese, D.G., Westgate, J.A., Barendregt, R.A., Villeneuve, M., Jackson, L.E., Baker, J., Enkin, R., Irving, E., Hart, C., Preece, S., Sandhu, A., 2001. Normal magnetization at ca. 1.5 Ma at three sites in Yukon Territory. Eos Transactions American Geophysical Union (AGU) 82 Fall Meeting supplement, abstract GP51A-0290.

Grond, H.C., Churchill, S.J., Armstrong, R.L., Harakal, J.E., Nixon, G.T., 1984. Late Cretaceous age of Hutshi, Mt. Nansen and Carmacks Groups, southwestern Yukon. Canadian Journal of Earth Sciences 21, 554-558.

Guthrie, R.D., Matthews Jr., J.V., 1971. Cape deceit fauna-early Pleistocene mammalian assemblage from the Alaskan Arctic. Quaternary Research 1, $474-510$.

Hamblin, W.K., 1994. Late Cenozoic Lava Dams in the Western Grand Canyon, vol. 183. Geological Society of America Memoir, p. 139.

Hickson, C.J., 2000. Physical controls and resulting morphological forms of Quaternary ice-contact volcanoes in western Canada. Geomorphology 32 (3-4), 239-261.

Hickson, C.J., Edwards, B.R., 2001. Volcanoes and volcanic hazards in Canada. In: Brooks, G.R. (Ed.), A Synthesis of Geological Hazards in Canada, vol. 548. Geological Survey of Canada Bulletin, pp. 1-248.

Hickson, C.J., Moore, J.G., Calk, L.C., Metcalf, P., 1995. Intraglacial volcanism in the Wells-Gray volcanic field, east-central British Columbia. Canadian Journal of Earth Science 32, 838-851.

Hunt, P.A., Roddick, J.C., 1992. A Compilation of K-Ar Ages: Report 21. Geological Survey of Canada, Paper 92-2, pp. 179-226.

Huscroft, C.A., 2002a. Late Cenozoic history of Yukon River Valley, Fort Selkirk to Stevenson Ridge map area. Unpublished MSc. thesis, Simon Fraser University, $153 \mathrm{pp}$.

Huscroft, C.A., 2002b. Surficial Geology, Cripple Creek, Yukon Territory. Geological Survey of Canada. Open File 4346, 1:50 000 map.

Huscroft, C.A., Barendregt, R.W., Jackson Jr., L.E., 2001. Late Cenozoic Geology, Ancient Pacific Margin NATMAP Project, Report 4: Paleomagnetic and Geomorphic Evidence for Brunhes-Age Volcanism, Fort Selkirk and Rosebud Creek Area, Yukon Territory. Geological Survey of Canada. Current Research 2001-A4.

Huscroft, C.A., Ward, B.C., Barendregt, R.W., Jackson Jr., L.E., 2004. Pleistocene volcanic damming of Yukon River and age of Reid Glaciation, west central Yukon. Canadian Journal of Earth Sciences 41, 151-164.
Jackson Jr., L.E., 1989. Pleistocene Subglacial Volcanism Near Fort Selkirk, Yukon Territory. Current Research, Part E, Geological Survey of Canada, paper 89-1E, pp. 251-256.

Jackson Jr., L.E., 2000. Quaternary Geology of the Carmacks Map Area, Yukon Territory, vol. 539. Geological Survey of Canada Bulletin. 74.

Jackson Jr., L.E., Stevens, W., 1992. A recent eruptive history of Volcano Mountain, Yukon Territory. Current Research, Part A. Geological Survey of Canada, pp. 33-39.

Jackson, L.E., Gordey, S.P., Armstrong, R.L., Harakal, J.E., 1986. Bimodal Paleogene volcanics near Tintina Fault, east-central Yukon, and their possible relationship to placer gold. In: Yukon Geology. Exploration and Geological Services Division, Yukon, vol. 1. Indian and Northern Affairs Canada, pp. 139-147.

Jackson Jr., L.E., Ward, B.C., Duk-Rodkin, A., Hughes, O.L., 1991. The last Cordilleran ice Sheet in southern Yukon Territory. Geographie physique et Quaternaire 45, 341-354.

Jackson Jr., L.E., Barendregt, R.W., Baker, J., Irving, E., 1996. Early Pleistocene volcanism and glaciation in central Yukon: a new chronology from field studies and paleomagnetism. Canadian Journal of Earth Sciences 33, 904-916.

Jackson, L.E., Huscroft, C.A., Ward, B.C., Villeneuve, M., 2008. Age of volcanism of the Wolverine volcanic center, west-central Yukon territory, Canada and its implications for the history of Yukon River. EOS, Transactions. American Geophysical Union 89 (53) Fall Meeting. Supplement, Abstract V41D-2110.

Kelman, M.C., 2005. Glaciovolcanism at the Mount Cayley volcanic field, Garibaldi Volcanic Belt, southwestern British Columbia. Unpublished Ph.D. thesis, Geological Science, The University of British Columbia, p. 258.

Kelman, M.C., Russell, J.K., Hickson, C.J., 2002. Effusive intermediate glaciovolcanism in the Garibaldi volcanic belt, southwestern British Columbia, Canada. In: Smellie, J.L., Chapman, M.G. (Eds.), Volcano-Ice Interactions on Earth and Mars. Geological Society Special Publication 202, pp. 195-212.

Kiss, F., Coyle, M., 2009. Residual Total Magnetic Field, McQuesten Aeromagnetic Survey. NTS 115I/13 and 115I/14, Yukon. Geological Survey of Canada. Open File 6106; Yukon Geological Survey, Open File 2009-4, scale 1:50 000.

Lisiecki, L.E., Raymo, M.E., 2005. A Pliocene-Pleistocene stack of 57 globally distributed benthic ${ }^{18} \mathrm{O}$ records. Paleoceanography 20, PA1003. doi:10.1029/ 2004PA001071.

Lisiecki, L., Raymo, M.E., 2007. Plio-Pleistocene climate evolution: trends in obliquity and precession responses. Quaternary Science Reviews 26, 56-69.

Long, P.E., Wood, B.J., 1986. Structures, textures, and cooling histories of Columbia River basalt flows. Geological Society of America Bulletin 97, 1144-1155.

Lyle, P., 2000. The eruption of multi-tiered columnar basalt lava flows. Journal of the Geological Society, London 157, 715-722.

Mathews, W.H., 1947. 'Tuyas' flat topped volcanoes in northern British Columbia. American Journal of Science 245, 560-570.

Mathews, W.H., 1986. Physiography of the Canadian Cordillera. Geological Survey of Canada. Map 1701A. Scale 1:5000 000.

Matthews Jr., J.V., 1974. Quaternary environments at Cape Deceit (Seward Peninsula, Alaska): evolution of a tundra ecosystem. Geological Society of America Bulletin 85, 1353-1354.

Naeser, N.D., Westgate, J.A., Hughes, O.L., Péwé, T.L., 1982. Fission-track ages of late Cenozoic distal tephra beds in the Yukon Territory and Alaska. Canadian Journal of Earth Sciences 19, 2167-2178.

Nelson, F.E., 2006. Late Cenozoic magnetostratigraphy of the Selkirk volcanics and associated sediments, west central Yukon. Unpublished MSc. thesis, Department of Geography, University of Lethbridge. 123 p.

Nelson, F.E., Barendregt, R.W., Villeneuve, M., 2009. Stratigraphy of the Fort Selkirk volcanogenic complex in central Yukon and its paleoclimatic significance: $\mathrm{Ar} / \mathrm{Ar}$ and paleomagnetic data. Canadian Journal of Earth Science 46, 381-401.

Owen, E.B., 1959a. Fort Selkirk Dam Site. Geological Survey of Canada, Topical Report No. 15, p. 12.

Owen, E.B., 1959b. Fort Selkirk Saddle Dam Site. Geological Survey of Canada, Topical Report No. 16, p. 9.

Parker, D.I., Lawhead, D.E., Cook, J.A., 1997. Distributional limits of bats in Alaska. Arctic 50, 256-265.

Raymo, M.E., Huybers, P., 2008. Unlocking the mysteries of the ice ages. Nature 451, 284-285.

Repenning, C.A., Brouwers, E.M., 1992. The Beringian ancestry of Phycotymys (Rodentia: Cricetidae) and the beginning of modern Arctic Ocean borderland biota. U.S. Geological Survey Bulletin 2036, 1-37.

Roddick, J.A., Mathews, W.H., Woodsworth, J.G., 1977. Trip 9-Southern End of the Coast Plutonic Complex. Geological Association of Canada, Mineralogical Association of Canada, Society of Economic Geologists, Canadian Geophysical Union, Joint Annual Meeting (Vancouver). Fieldtrip Guidebook, 29 p.

Ryan, J.J., Colpron, M., Hayward, N., 2010. Geology, Southwestern McQuesten and Parts of Northern Carmacks, Yukon. Geological Survey of Canada. Canadian Geoscience Map 7, scale 1:125 000.

Sanborn, P., 2010. Soil reconnaissance of the Fort Selkirk volcanic field, Yukon (115I/ 13 and 14). In: MacFarlane, K.E., Weston, L.H., Blackburn, L.R. (Eds.), Yukon Exploration and Geology 2009. Yukon Geological Survey, pp. 293-304.

Sandhu, A.S., Westgate, J.A., Preece, S.J., Froese, D.G., 2001. Glass-fission-track ages of Late Cenozoic distal tephra beds in the Klondike district, Yukon Territory. In: Emond, D.S., Weston, L.H. (Eds.), Yukon Exploration and Geology 2000. Exploration and Geological Services Division, Yukon. Indian and Northern Affairs Canada, pp. 247-256.

Scaillet, S., 2000. Numerical error analysis in ${ }^{40} \mathrm{Ar} /{ }^{39} \mathrm{Ar}$ dating. Chemical geology 162 (3-4), 269-298. doi:10.1016/S0009-2541(99)00149-7. 
Shimamura, K., Froese, D., Jackson Jr., L.E., 2000. Late Cenozoic Geology, Ancient Pacific Margin NATMAP, Report 1: Long-Baseline, Dual-Frequency, GPS Static Positioning Trial, Stewart River Map Area, Yukon Territory. Geological Survey of Canada. Current Research 2000-A2, 6p.

Sinclair, P.D., Tempelman-Kluit, D.J., Medaris Jr., L.G., 1978. Lherzolite nodules from a Pleistocene cinder cone in central Yukon. Canadian Journal of Earth Sciences $15,220-226$.

Skilling, I.P., 2002. Basaltic Lava-Fed Deltas: Large Scale Characteristics, Clast Generation, Emplacement Processes and Environmental Discrimination, vol. 202. Geological Society of London. 91-113.

Skilling, I.P., 2009. Subglacial to emergent basaltic volcanism at Hlöđufell, southwest Iceland: a history of ice confinement. Journal of Volcanology and Geothermal Research 185, 276-298.

Smellie, J.L., 2006. The relative importance of supraglacial versus subglacial meltwater escape in basaltic subglacial tuya eruptions: an important unresolved conundrum. Earth Science Reviews 74, 241-268.

Storer, J.E., 2003. The eastern Berigian vole Microtus deceitensis (Rodentia, Muridae, Arvicolinae) in Late Pliocene and Early Pleistocene faunas of Alaska and Yukon. Quaternary Research 60, 84-93.

Storer, J.E., 2004. A new species of Mustela (Mammalia; Carnivora; Mustelidae) from the Fort Selkirk Fauna (Early Pleistocene) of Yukon Territory, Canada. Paludicola 4, 151-155.

Tempelman-Kluit, D.K., 1984. Geology, Laberge (105E) and Carmacks (115I), Yukon Territory. Geological Survey of Canada. Open File 1101, 1:250 000.

Udagawa, S., Kitagawa, H., Gudmundsson, A., Hiroi, O., Koyaguchi, T., Tanaka, H., Kristjansson, L., Kono, M., 1999. Age and magnetism of lavas in Jokuldalur area, Eastern Iceland: Gilsa event revisited. Physics of the Earth and Planetary Interiors 115 (2), 147-171.

Villeneuve, M.E., MacIntyre, D.G., 1997. Laser ${ }^{40} \mathrm{Ar} /{ }^{39} \mathrm{Ar}$ ages of the Babin porphyries and Newman Volcanics, Fulton Lake map area, west-central British Columbia. In: Radiogenic Age and Isotopic Studies. Geological Survey of Canada, Report 10, Current Research 1997-F, pp. 131-139.
Villeneuve, M.E., Sandeman, H.A., Davis, W.J., 2000. A method for inter calibration of $\mathrm{U}-\mathrm{Th}-\mathrm{Pb}$ and ${ }^{40} \mathrm{Ar} /{ }^{39} \mathrm{Ar}$ ages in the Phanerozoic. Geochimica et Cosmochimica Acta 64 (23), 4017-4030. doi:10.1016/S0016-7037(00) 00484-1.

Ward, B.C., Jackson Jr., L.E., 1992. Late Wisconsinan glaciation of the Glenlyon Range, Pelly Mountains, Yukon Territory, Canada. Canadian Journal of Earth Sciences 29, 2007-2012.

Ward, B.C., Bond, J.D., Froese, D., Jensen, B., 2008. Old Crow tephra (140 $\pm 10 \mathrm{ka})$ constrains Reid Glaciation in central Yukon Territory. Quaternary Science Reviews 27, 1905-1915.

Westgate, J.A., 1989. Isothermal plateau fission-track ages of hydrated glass shards from silicic tephra beds. Earth and Planetary Science Letters 95, 226-234.

Westgate, J.A., Froese, D.G., 2005. Stop 12: Quartz Creek-Pliocene ice wedges and Quartz Creek tephra. In: Froese, D.G., Westgate, J.A., Galloway, B.V. (Eds.), Field Guide for the International Field Conference and Workshop of Tephrochronology and Volcanism: Dawson City, Yukon Territory, Canada, July 31st to August 8th, 2005. Institute of Geological \& Nuclear Sciences Limited, New Zealand, pp. 105-108. Science report 2005/26.

Westgate, J.A., Preece, S.J., Froese, D.G., Walter, R.C., Sandhu, A.S., Schweger, C.E. 2001. Dating Early and Middle (Reid) Pleistocene glaciations in central Yukon by tephrochronology. Quaternary Research 56, 335-348.

Westgate, J.A., Preece, S.J., Froese, D.G., Telka, A.M., Storer, J.E., Pearce, N.J.G. Enkin, R.J., Jackson Jr., L.E., LeBarge, W., Perkins, W.T., 2009. Gold Run tephra: Middle Pleistocene stratigraphic marker across west-central Yukon Territory, Canada. Canadian Journal of Earth Science 46, 465-478.

White, J.D.L., Houghton, B.F., 2006. Primary volcaniclastic rocks. Geology 34 677-680.

Williams, H., McBirney, A.R., 1979. Airfall and Intrusive Pyroclastic Deposits Volcanology. Freeman, Cooper and Company, San Francisco, p. 180 (Chapter 6)

Yang, T., Hyodo, M., Yang, Z., Ding, Lin, Fu, J., Mishima, T., 2007. Early and middle Matuyama geomagnetic excursions recorded in the Chinese loess-paleosol sediments. Earth, Planets and Space 59, 825-840. 